\title{
Kernos
}

Revue internationale et pluridisciplinaire de religion grecque antique

$22 \mid 2009$

Varia

\section{Epigraphic Bulletin for Greek Religion 2006 (EBGR 2006)}

\section{Angelos Chaniotis}

\section{(2) OpenEdition \\ Journals}

Electronic version

URL: http://journals.openedition.org/kernos/1787

DOI: 10.4000/kernos. 1787

ISSN: 2034-7871

\section{Publisher}

Centre international d'étude de la religion grecque antique

Printed version

Date of publication: 1 January 2009

Number of pages: 209-243

ISSN: 0776-3824

\section{Electronic reference}

Angelos Chaniotis, « Epigraphic Bulletin for Greek Religion 2006 (EBGR 2006) », Kernos [Online], 22 | 2009, Online since 26 October 2012, connection on 15 September 2020. URL : http:// journals.openedition.org/kernos/1787 
Kernos 22 (2009), p. 209-243.

\section{Epigraphic Bulletin for Greek Religion 2006 (EBGR 2006)}

The 19th issue of the Epigraphic Bulletin for Greek Religion presents a selection of the epigraphic publications of 2006 and several additions to earlier issues. Following the practice of the last issues, emphasis was placed on the presentation of new corpora and editions of new texts. We note the publication of two corpora containing inscriptions from Thessalonike (88) and Antiocheia in Pisidia (21). This issue also contains several interesting new texts. Undoubtedly, the most important is the dossier of letters of Hadrian, which provides detailed information on the organisation of agonistic festivals (114). An interesting expression of religious experience is an inscription from Aizanoi, which reports how the dreadful fear felt by a certain Menophilos (on account of a vision?, of divine punishment?) lead to the foundation of the cult of Great Zeus of Menophilos (95). Divine punishment seems also to have forced an individual to dedicate a slave to Artemis Ephesia in Macedonia (9). An interesting dedication from Kallipolis (4th/3rd cent., 101) is designated as $\lambda$ voiiov $\alpha$ ('expression of gratitude for the end of suffering'); this texts is also a very rare attestation of the cult of Nyx. A new 'confession inscription' is now added to the corpus of this intriguing group of texts (78).

A new sacred regulation from Thasos (55) concerns order in a sanctuary of the Delian gods; another sacred regulation can now be restored as a regulation concerning the sale of the priesthood of the gods of the council at Kos (57). Regarding the imperial cult, important new evidence has come to light in Metropolis (Ionia, 38), including an altar for Augustus Heilasterios and a new copy of the dossier of documents concerning the celebration of his birthday in Asia. An inscription from Rhodiapolis (63) refers to the construction at the expense of a woman of a crown decorated with images of the emperors, probably the crown of the high priestess of the imperial cult. Another important group of new texts are the Latin curse tablets from Mainz (15), which show great affinity with prayers for justice from the Hellenistic and Roman East. We also single out a long funerary oration from Pantikapaion (17), which assimilates the deceased with Chiron.

The principles explained in Kernos 4 (1991), p. 287-288, and Kernos 7 (1994), p. 287, also apply to this issue. Abbreviations which are not included in the list of abbreviations are those of L'Année Philologique and J.H.M. STRUBBE (ed.), Supplementum Epigraphicum Graecum. Consolidated Index for Volumes XXXVI-XLV (1986-1995), Amsterdam, 1999, as well as of later volumes of the SEG. If not otherwise specified, dates are BC. Aneurin Ellis-Evans (Balliol College, Oxford) has improved the English text. 


\begin{abstract}
Abbreviations

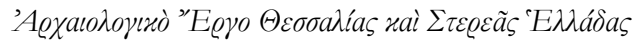

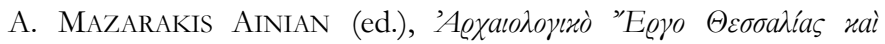

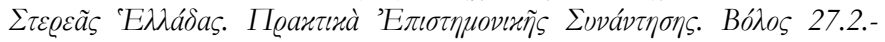
2.3.2003, Volos, 2006.

AST 23 23. Arastirma Sonuçari Topalntisi. 30 Mayis-3 hą̧iran 2005, Antalya, Ankara, 2006.

Donna e vita A. BuOnapane - F. CEnerini (eds.), Donna e vita cittadina nella documentazione epigrafica. Atti del II Seminario sulla condizione femminile nella documentazione epigrafica. Verona, 25-27 marzo 2004, Rome, 2005.

Greek Sacrificial Ritual R. HÄGG - B. Alroth (eds.), Greek Sacrificial Ritual, Olympian and Chthonian. Proceedings of the Sixth International Seminar on Ancient Greek Cult, Organized by the Department of Classical Archaeology and Ancient History, Göteborg University, 25-27 April 1997, Stockholm, 2005.

Histria VII

P. AlEXANDRESCU et al., Histria. Les résultats des fouilles. VII. La zone sacrée d'époque grecque (Fonilles 1915-1989), Bukarest, 2005.

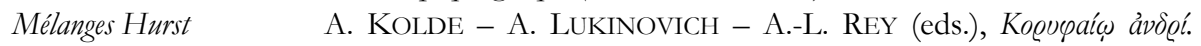
Mélanges offerts à André Hurst, Geneva, 2005.
\end{abstract}

\title{
Selected Topics
}

Geographical areas (in the sequence adopted by SEG)

Attica: Athens: 4. 19. 27-29. 31. 45. 91. Peloponnesos: Troizenia: Troizen: 66. Epidauros: 45. 87. Messenia: Andania: 19. 28. 36. 98; Messene: 110. Elis: Olympia: 109. Boiotia: 31. 85; Lebadeia: 16; Thebes: 5; Thespiai: 27. 39. Delphi: 45. 96. 103. Phokis: Elateia: 122. Aitolia: Kallipolis: 101. Lokris: Naryx: 67; Physkos: 102. Ionian Islands: Korkyra: 44. Thessaly: Itonos: 62; Larisa: 59. 113. Epeiros: Dodona: 74. Illyria: 44; Bouthrotos: 97; Grammata: 22. Dalmatia: 23. 44. Macedonia: 9. 14. 77. 92. 121; Beroia: 71; Dion: 89-90; Kallindoia: 106; Leukopetra: 119; Pella: 1; Philippi: 18; Thessalonike: 88. Moesia. Histria: 2. 13. 55. North Shore of the Black Sea: Bosporan kingdom: 112; Olbia: 20. 55. 72; Pantikapaion: 17. Delos: 27-28. 40. 45. 56. 105. Mykonos: 19. Rhodes: 19. 100; Lindos: 68. Thera: 27. Kos: 19. 28. 57. Ios: 27. Paros: 27. 54. Peparethos: 37. Andros: 103. Chios: 27. Samos: 85. Thasos: 11. 46-48. 54. 85. Euboia: Zarax: 56. Crete: 84; Gortyn: 19; Knossos: 10. Sicily: 118; Comiso: 11; Leontinoi: 49; Selinous: 60. 91. Italy: 118; Forum Fulvii: 52; Lokroi Epizephyrioi: 76; Pozzuolo: 82; Rome: 24. Germania: 15. Asia Minor: 30. 117. Karia: Amyzon: 33; Halikarnassos: 32. 64-66. 107; Hyllarima: 116; Keramos: 108; Knidos: 27; Stratonikeia: 7-8; Ouranion: 114. Ionia: Ephesos: 85; Erythrai: 28; Kolophon: 51; Magnesia on the Maeander: 85; Metropolis: 38; Miletos: 3. 19. 55. 85; Priene: 27. 31; Smyrna: 85; Teos: 33. 75. Lydia: 78-81; Sardeis: 33. Mysia: Germe: 53; Pergamon: 27. 75. 85. Phrygia: Aizanoi. 73; Akmonia: 115. Pisidia: Antiocheia: 21. Lykia: 34. 42; Myra: 104; Oinoanda: 86; Rhodiapolis: 63; Xantos: 33. Syria-Palaestina: 30; Gerasa: 99; Sidon: 119. Arabia: Ikaros: 94. Cyprus: Amathous: 6. 61. Kommagene : 43. Arabia: 50. Egypt: 58. 69; Alexandria: 27; Naukratis: 41.55

acclamation: 73

afterlife: 24

Alexander the Great: 88 
altar: 8

amphictyony: 67 (Delphi). 109 (Olympia)

amulet: $12 ; i f$. phylactery

animals: cobra: 69; goat: 11; ox: 11; pig: 11. 28; ram: 56; sacrificial: 11. 19. 28; pregnant: 19. 28

association, cult: 27.75 .88

asylia: 94

banquet: 1.11.21.88. 91

benefactor: 48

birthday: 51; of emperor: 38

calendar: 101 (Lokris)

cession of property to gods: 15

chthonian, sacrifice: 28. 60. 91

confession: 15; confession inscriptions: 35.76 .78

contest: 51. 117. 119; athletic: 108; musical: 75

council, cults in: 57

crown, priestly: 57.63

cult, emperor: 6. 18. 21. 38. 42. 46. 67. 88. 93. 99. 106. 114. 119; of poets: 27 ; ruler c.: 33. 51. 65. $119-120$

cult, founder: 73. 79. 88; introduction of: 10. 40. 54; Italian influence: 97

cult personnel: agonothetes: 21. 88. 95. 102. 110. 119; augur: 21; archiereia of the provincial emperor cult, in Macedonia: 93; archiereus: 21; of Hellenistic ruler cult: 33. 119; of civic emperor cult: 88. 119; of provincial emperor cult in Achaia: 110; in Lykia: 42. 86; brabeutes: 21; flamen: 18; hieraphoros: 119; hiereia: 4. 53. 63. 119; of civic emperor cult: 46. 63. 93; hiereus: 21. 53. 57. 79. 88-89. 115. 119; of civic emperor cult: 18. 38; hieromnemon: 54; hieropoios: 54; protanaklites: 21; proxenos: 109; sacerdos: 21 . 88; theekolos/theokolos: 67. 109

cult regulation: 19.36 .54 .57 .60

curse: 15. 29. 76; see also funerary imprecation, prayer for justice

dedication: 68; of a child: 121 ; of a slave: 121 ; by an association: 119 ; by a herald: 118 ; by a priest: 89.119 ; in commemoration of war victory: 5.39 .112 ; for the well-being of an association: 119 for the well-being of a family member: 80. 119; for the well-being of master: 21; for the well-being of the royal family: 61; for the well-being of a member of the imperial family: 46. 88; in expression of gratitude: 42. 119; upon divine command: 8-9. 73; upon an oracle: 43

deities: Aphrodite: 2. 6. 13. 40. 44. 55. 61. 66. 99. 119; Akraia 66; Kypria 6; Schoinis 32. Apollon: 37. 41. 65. 73. 92. 96. 99. 116; Delios 55-56; Germenos 53; Letros 2; Kerdoios 59. 113; Klarios 51; Phoibos 112. Artemis: 8. 19. 21. 48. 99. 101; Agoraia 102; Akraia 88; Delia 54; Ephesia 9; Epikrateia 70; Gourasia 88. Asklepios: 37. 73. 87-88. 99. 119; Sebastos 115; Soter 90. Athena: 4. 87. 99. 102; Ilias 101; Itonia 62; Kranaia 122; Sebaste 115; Skiras 19. Boreus: 2. Charites: 102. Demeter: 19. 36. 72. 99; Chloe 19. Dionysos: 88. 112; Horophoros 88; Kadmeios 119. Dioskouroi: 10. 15. 22. 36; Soteres 50. Eros: 44. Ge: 19. Hekate: 73. Hera: 13. 49. 99; Antheia 19; Boulaia 57. Herakles: 11. 17. 88. 99. Hermaphroditos: 107. Hermes: 115. Hosion kai Dikaion: 73. 88. 
Kore: 72-73. Leto: 99. Mes: 21; Axiottenos 81. Meter: 73; Epiktetos 73; Motyllene 76; Oreia 42; Theon 63. 72-73. 121. Mousai: 27. Nemesis: 88; Epekoos 21. Nyx: 101. Pan: 97. Pasa: 97. Phorkys: 2. 13. Plouton: 72. Poseidon: 17. 88. 99: Isthmios 66. Rhea: 19. Rhome: 106. 119. Soteira: 94. Thea: Andeine 79; Peismatene 53. Themis: Agoraia 102(?). Theoi: 21. 104; Boulaioi 57; Pantes 42. Theos: Epekoos 21; Hypsistos 42. 88; Megas 2. Tyche: 71. Zeus: 13. 32-33. 44. 73. 89. 99. 106. 118; Agoraios 102. 118; Aulaios 53; Boulaios 57; Bronton 73; Dolichenos 43; Hikesios 118; Hypsistos 14; Kassios 44; Kerannios 80. 115; Meilichios 118; Odarios 102, Olympios 73; Orios 118; Philios 1-2; Saotas 39; Sabazios 73; Soter 8. 118.

deities: Egyptian: 10. 15. 58. 61. 66. 88; Anatolian: Attis 15; Kybele 15. 53; Mater Magna 15; Roman: Bellona 15; Oriental: Eshmoun 119; Mithras 119

deities, assimilation of Greek and foreign god: 119; descent from: 17 (from Herakles and Poseidon). 88 (Alexander from Zeus); dyads: 97; patrons of fertility: 88; of sailors: 22. 50; tribes named after d.: 99

devotion: 73

disease: 52

divination: 16.43 .74

dream: 73

emotionality in ritual: 26

epiphany: 68.73

epithet, deriving from acclamation: 73

exorcism: 12

fate: 7

fear: 73

fertility: 28

festival: 95. 117; crowning during: 57; order during: 36

festivals: Aktia Kabeiria Kaisareia Pythia: 88 (Thessalonike); Dionysia: 110 (Messene); Echenikeia: 40 (Delos); Eleutheria: 21 (Plataia); Karneia: 36; Maximianeia: 21 (Antiocheia in Pisidia); Paneia: 25 (Delos); Sarapeia Apollonia 63 (Rhodiapolis); Soteria: 25 (Delos, Delphi); Stesileia: 40 (Delos); Thesmophoria: 28. 54; Trophonia: 16 (Lebadeia)

finances, sacred: 85.96

fortune: 71

foundation: 21

funerary cult: 21. 30. 34. 47. 73. 88; burial of members of associations 88; emotionality in funeral: 26; funerary altar dedicated to a god: 73; imprecation: 21. 73. 81. 86. 104; oration: 17 ; public funeral: 30.47

gem, magical: 53

gladiators: 7.21 .71 .88

grave, protection of: 30. 88. 104; see also funerary imprecation

gymnasion: 51

healing: 52

hero: 5 (Euonymos, Kadmos). 9. 13. 16 (Trophonios). 17. 20 (Achilles). 23 (Diomedes). 77 (Auloneites). 88 (Aineias); sacrifice to: 91 
heroization: 30.34 .89

Homer: 27

identity: 36

inventory: 96

Jews: magic: 12

kinship, mythological: 31.59

lex sacra: see cult regualation

libation: 1.58

magic: 15; see also amulet, curse, exorcism, prayer for justice

manumission, sacred: 9. 102. 121

music: 3

mystery cult: $36.97-98$

myth: 17. 59. 64. 66-67. 88. 107; mythological kinship: 31

name, theophoric: 111

oath: 36

Orpheus: 2

Panhellenion: 67

perirrhanterion: 87

personification: 101 (Nyx)

phylactery: 52.82

piety: 35.115

politics and religion: 25. 36. 94

prayer: 57 ; for justice: 15.69 .76

priesthood, hereditary: 79; for life: 21. 63. 115; sale of: 57; list of priests: 66.116

private cult: 40

procession: 36.120

punishment, divine: 9. 54. 73.78

purification: 28. 60.91. 118

relics: 68

rituals: see cession of property to gods, libation, sacrifice, supplication, transition rite river-god: 105.111

sacrifice: 11. 19. 28. 36. 51. 91. 100. 120; of pregnant animals: 19; plunging of animals into the sea 100; consumption of meat on the spot: 91 ; distribution of meat: 57 ; see also animals

sacrilege: 109

sanctuary: 6. 45; federal: 62. 122

sanctuary, administration: 45; boundary stone: 6. 8. 41; building activities: 45. 48. 84. 114; deposits of money: 96; finances: 45. 96; foundation of: 15; keeping of livestock: 54; land belonging to: 11 ; order in: 54.109 ; prohibition of entering a s.: 54 ; protection of: 54.105 
slave: $15.21-22$

soul: 76

statue: 57.115 ; removal of: 114

supplication: 36.38

theoria: 103

transition rite: 19

vision: 73

vow: 50

water: 105

women, participation in cult: 11. 54; priestesses: 93

\section{Greek words (a selection)}

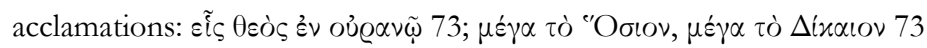

amulet: $\sigma \tilde{\omega} \zeta \varepsilon 82$

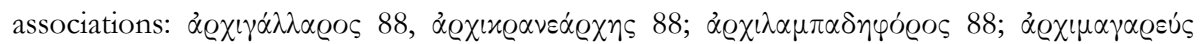

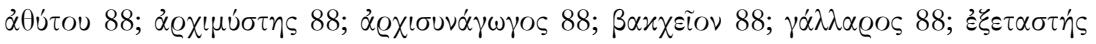

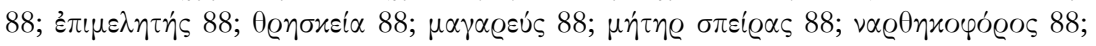

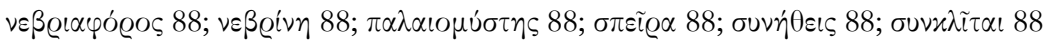

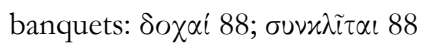

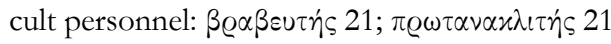

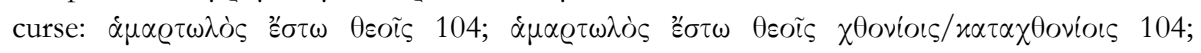

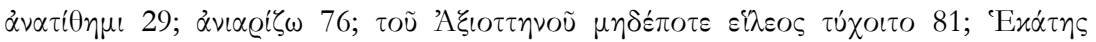

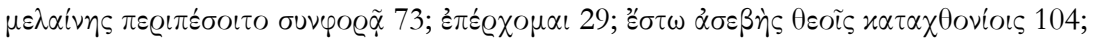

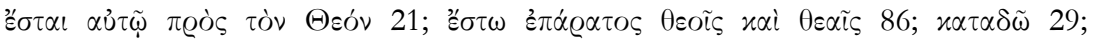

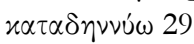

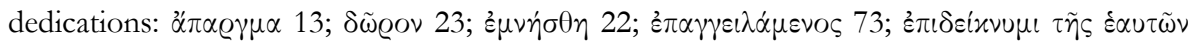

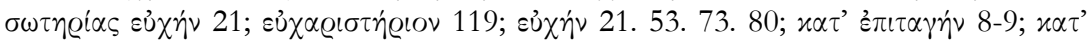

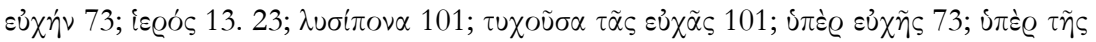

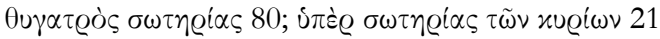

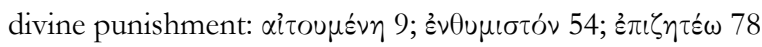

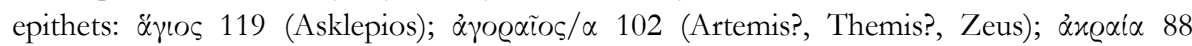

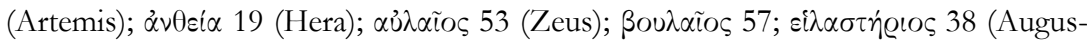

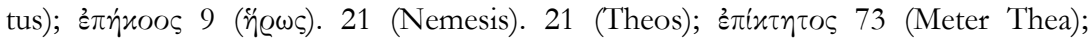

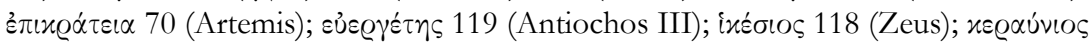

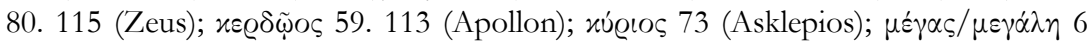

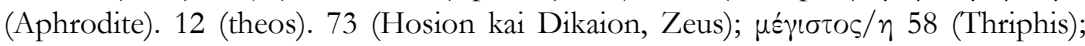

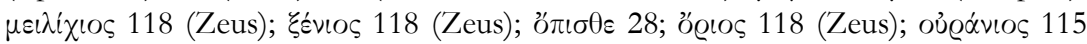

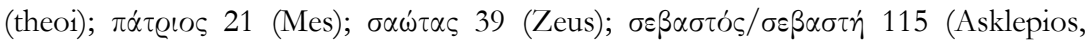

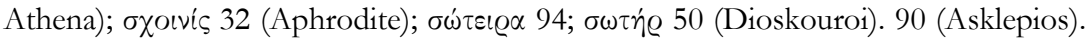

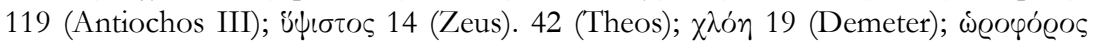
88 (Dionysos)

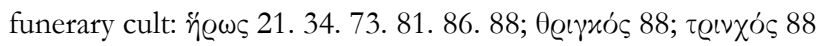

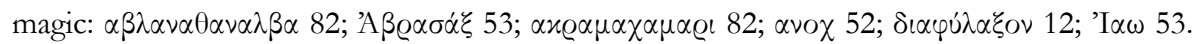

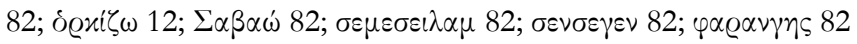




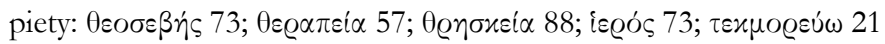

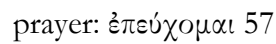

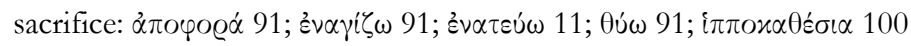

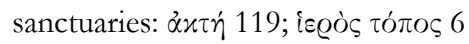

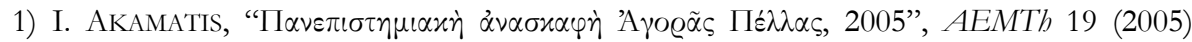
[2007], p. 407-426 [SEG LV 705]: Ed. pr. of a black kantharos found in the Agora of Pella (Hellenistic period). The vase was inscribed before firing with the text 'of Zeus Philios' (p. 422; cf. SEG XLV 780). [The inscription shows that this kantharos was used for libations for Zeus Philios, the patron of friendship, during banquets.]

2) P. Alexandrescu - M. Alexandrescu Vianu, "Histoire et stratigraphie", in Histria VII, p. 51-156: The authors present an overview of the deities, who were worshipped in the 'sacred area' of Histria (6th-1st cent.), on the basis of epigraphic finds: Aphrodite, Boreus,

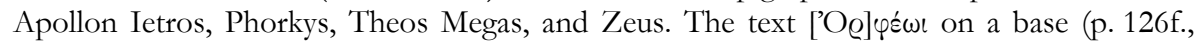
Hellenistic) may be a dedication to Orpheus.

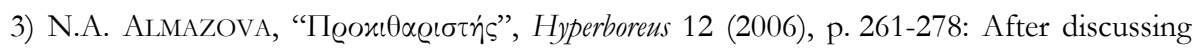
the various connotations of pro- in composite words, A. argues that pro- in prokitharistes in Miletos (I.Didyma 182 and 265; MDAI(I) 15 [1965], p. 122) designates a leading citharist performing during ceremonies.

4) N. Andriolo, "Chrysis, sacerdotessa di Athena: IG, II/III2, 1136", in Donna e vita, p. 439-445: Commentary of an honorary decree of Delphi for Chrysis, priestess of Athena (IG II ${ }^{2}$ 1136, 117 BC) [no new insights].

5) V.L. Aravantinos, “A New Inscribed Kioniskos from Thebes”, ABSA 101 (2006), p. 369-377: Ed. pr. of a fragmentary dedicatory inscription (epigram?) inscribed on a small column that supported a dedication (a tripod?). It was found in a deposit of the late Archaic period at Pyri, a suburb of Thebes [cf. SEG LIV 518]. The votive was dedicated to an anonymous deity or hero (perhaps Kadmos or the Boiotian hero Euonymos) in commemoration of the military activities of Theban troops during the invasion of Attika by Kleomenes and his allies in 506 BCE (Herod., V, 77). The text seems to refer to the temporary occupation of Oinoe, Phyle, and Eleusis (possibly Hysiai too) by the Theban troops and the liberation of captives from Chalkis. This campaign ended in a humiliating defeat of the Thebans, for which the Athenians erected a victory monument on the Acropolis (IG $\mathrm{I}^{3}$ 501). This dedication was not a riposte to the Athenian monument, but probably an effort by the troops to save face.

6) P. Aupert - A. Hermary, "Nouveaux documents sur le culte d'Aphrodite à Amathonte", BCH 130 (2006), p. 83-99: Ed. pr. of an inscription (Amathous, $79 \mathrm{CE}$ ), which records the restoration of a sanctuary of Titus and Aphrodite by the governor of Cyprus,

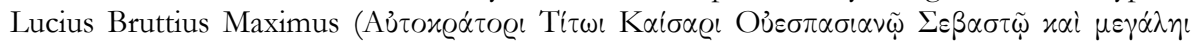

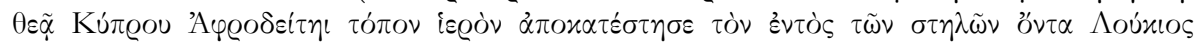

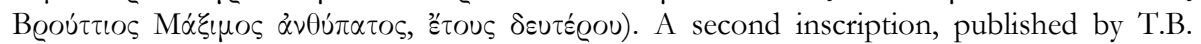
MITFORD ("Religious Documents from Roman Cyprus", JHS 66 [1946], p. 40-42), refers to activities of the same governor in connection with the same sanctuary; however, the second

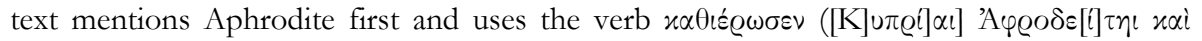

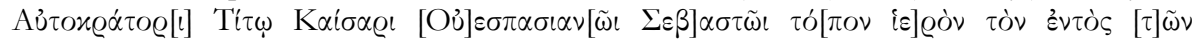

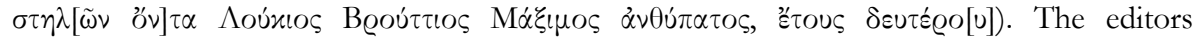
plausibly assume that besides the sanctuary of Aphrodite on the acropolis, there was a 
second sanctuary near the north gate, where a marble head of Aphrodite (?) was found. This

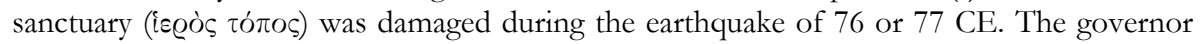
restored the sanctuary and dedicated it to the joined cult of Aphrodite and the emperor. The stelai mentioned in these texts refer to boundary markers of the sanctuary.

7) S. AYDAŞ, "Gladiatorial Inscriptions from Stratonikeia in Caria”, EA 39 (2006), p. 105109: Ed. pr. of six epitaphs of gladiators from Stratonikeia (3rd cent. CE), where gladiatorial combats were already attested (I.Stratonikeia 303, 1015, 1025). We single out the funerary

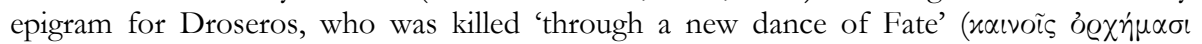
roíns) by the gladiator Achilles. [An interesting piece information is that the gladiator

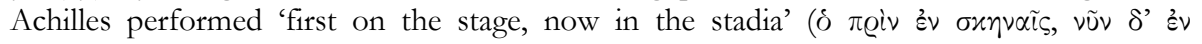
$\sigma \tau \alpha \delta i o \imath \sigma[\iota v])$; Achilles was an actor or a mime (Homeristes), before he became a gladiator; a good case of the performance of gladiatorial games in stadia is Aphrodisias: K. WELCH, "The Stadium of Aphrodisias", AJA 102 (1998), p. 559-561.]

8) S. AYDAŞ, “Three Inscriptions from Stratonikeia in Caria”, EA 39 (2006), p. 111-112: Ed. pr. of two inscriptions from Stratonikeia (Imperial period): a stone (boundary stone) [or altar?)] naming Zeus Soter and Karios (1) and a dedication to Artemis upon divine

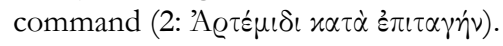

9) S. Babamova, Epigrafski spomenici od Republika Makedonija datirani spored Makedonskata provinciska era [Epigraphic Monuments of the Republic of Macedonia Dated According to the Macedonian Provincial Era], Skopje, 2005: B. presents a corpus of 83 inscriptions, mostly from the territory of FYROM. In the introduction she briefly discusses the local cults. Since most of the texts have been included in IG X 2.2 (summarized in EBGR 1999, 181), we do not present this publication in detail. But there are several inscriptions (not in $I G$ X 2.2), which deserve comment. A stele from Herakleia Lynkestis contains a dedication to Artemis Ephesia (35, 209 CE), whose cult is attested in Macedonia (IG X 2.2, 188 and 233). [B. presents only this dedication, inscribed on the lower part of the stele; but on the top, the stele contained a second (perhaps a third) dedication. We read part of the text on the top

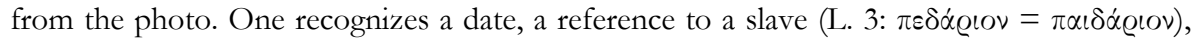
and the name of Artemis; it seems to be the dedication of a slave to Artemis Ephesia; for dedications of slaves in Macedonia see infra no. 121. The second text can be read in part;

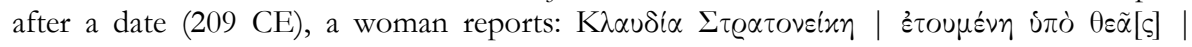

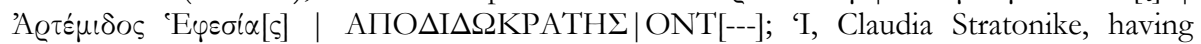
received a request from Artemis Ephesia, give --(?). Stratonike was the victim of divine

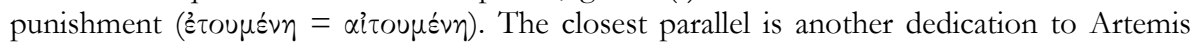

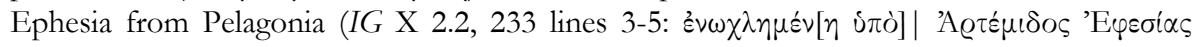

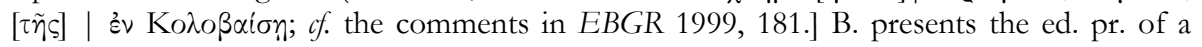
dedication to Heros Epekoos upon divine command ( $\varkappa \alpha \tau^{\prime}$ छ $\pi \iota \tau \alpha \eta \eta^{\prime}$; 83, $168 \mathrm{CE}$ ).

10) M.W. BALDWIN Bowsky, "From Capital to Colony: Five New Inscriptions from Roman Crete", ABSA 101 (2006), p. 385-426: Ed. pr. of two Latin inscriptions from Roman Knossos. An inscribed block names Castor in the dative (3, 1st cent. CE); this is the first attestation of the cult of the Dioskouroi in Knossos; the Dioskouroi are, however, represented in a dedicatory relief; the cult of Castor and Pollux may have been introduced by Italian colonists. B. discusses in detail the evidence for the cult of Castor and Pollux in the Roman East. Another inscription (2, 1st cent. CE) seems to name Isis; B. comments on the diffusion of Egyptian cults in Crete.

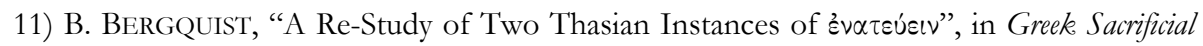

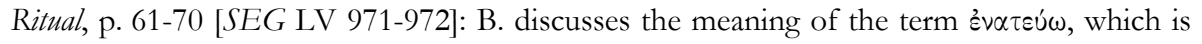


attested in Thasos in a cult regulation for the cult of Herakles (c. 450 BCE; IG XII Suppl. $414=$ LSCG Suppl. 63) and in a lease of a real estate belonging to Herakles (early 3rd cent.; IG XII Suppl. 353). The cult regulation, which forbids the sacrifice of goats and pigs, the participation of women, athletic contests, and priestly perquisites, uses this term in a negation: sacrifices are to be performed not according to the 'ninth-part sacrifice'. According to B., this negation is to be understood as a prescription: sacrifices should be followed by feasting. The aim of this regulation, originating in a private cult, was to relieve the cult from priestly perquisites and expensive contests. The other text is very fragmentary

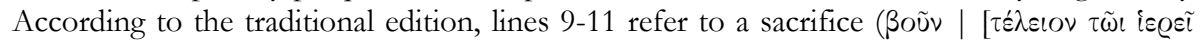

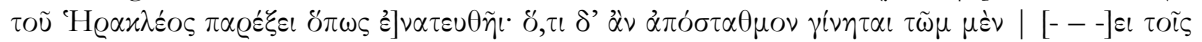

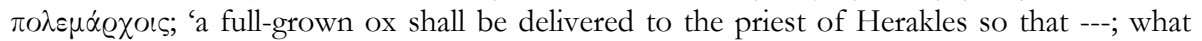
becomes weighed off, partly --- to the polemarchs'). B. argues that in this text too [ह] $\nu \alpha \tau \varepsilon \cup \theta \tilde{\eta} \iota$ was preceded by a negation; the ox delivered to the priest by the lessee of the garden was not to be sacrificed according to a 'ninth-part sacrifice'; this means that a sacrificial feasting was to be performed. [The text is heavily restored (two thirds are missing), and it is not at all certain that there was a negation before [ $\varepsilon$ ] $\nu \alpha \tau \varepsilon u \theta \tilde{\eta} l$ (a conditional sentence is also possible). It is not even certain that this is a clause prescribing a sacrifice. It is preceded by a clause concerning the dung of animals (lines 6-8; cf. line 17) and the misdemeanour of slaves (lines 8-9), and followed by a clause concerning trees (lines 12-13); the context is not that of a cult prescription, but that of a regulation concerning the proper use of the $x \tilde{\eta} \pi \circ \zeta$ by the leasee. The interpretation of $\dot{\alpha} \pi \dot{\sigma} \sigma \tau \theta \mu$ ov as 'weighed off' (or 'weight remaining after deduction esp. of the part of a victim reserved for the god', LSJ Supp.) is

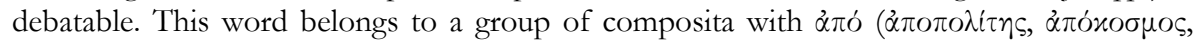

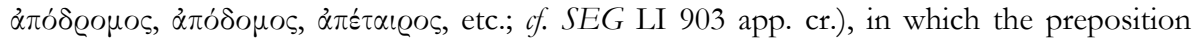
$\dot{\alpha} \pi \dot{o}$ indicates removal/rejection/distance from the second component of the word; consequently, $\alpha \pi \delta$ $\sigma \tau \alpha \theta \mu o v$ may not be 'away from the $\sigma \tau \alpha \theta \mu{ }^{\prime} v$ ' (the weight), but 'away from the $\sigma \tau \alpha \theta \mu$ ó $\varsigma^{\prime}$, i.e. away from the stable or the standing place for animals; this may be a clause concerning run-away animals ('whichever animal leaves the stable, etc.'). The riddles concerning év $\alpha \tau \varepsilon u ́ \varepsilon \iota \nu$ have not been solved by this article.]

12) G. Bevilacqua - F. De Romanis, "Nuova iscrizione esorcistica da Comiso”, RAL n.s. 9, 14 (2003), p. 389-402 [BE 2005, 91; SEG LIII 990]: Ed. pr. of a golden amulet found in the baths at Camiso in eastern Sicily (5th cent. CE). The amulet contains the exorcistic

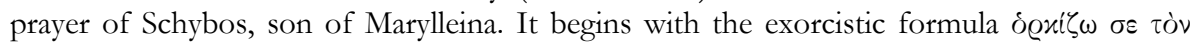

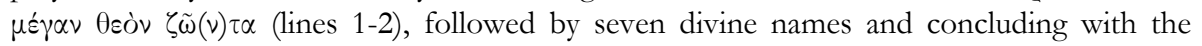

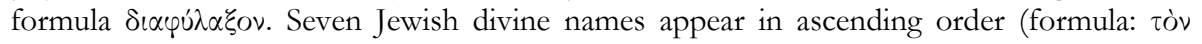

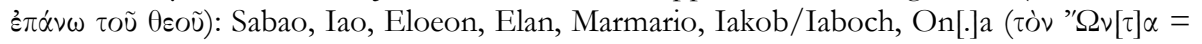
$\tau o ̀ v<\not ́>v[\tau] \alpha$ ?). This sequence, hitherto unattested, reflects the ascendance to Heaven. The amulet should be put against a Jewish-Christian background.

13) I. BîRZESCU, "Les graffiti", in Histria VII, p. 414-432: B. presents a catalogue of the graffiti and dipinti found in the 'sacred area' of Histria. Except for a tile dedicated to Aphrodite as $\ddot{\alpha} \pi \alpha \varrho \gamma \mu \alpha$ (G8 = I.Histriae 101), the other texts were written on vases. Some of them bear dedicatory inscriptions addressed to Zeus (G1-6), Hera (G7), Phorkys (G9), and Heros (G10-11). Two vases are designated as irgn (G11-12). Two dipinti with the letter $\Theta$ (G24-25) may refer to vases made for a sanctuary. [For a summary of these texts see id., "Histria. Graffiti din 'zona sacră’ dedicații către divinitați”, SCIVA 54-56 (2003-2005), p. 201-210.] 
14) V. Bitrakova Grozdanova, "Sur le culte des Zeus Hypsistos en Macédoine”, Živa Antika 56 (2006), p. 73-80: Ed. pr. of a dedication to Zeus Hypsistos (Marvinci, area of Doberos or Idomene?, ca. 150-200 AD).

15) J. BlänSDORF, "Cybèle et Attis dans les tablettes de defixio inédites du Mayence", CRAI (2005), p. 669-692: B. reports on the discovery of 34 lead tablets in a sanctuary hosting temples of Isis Panthea and Mater Magna (Kybele) in Mainz 1999. The sanctuary was founded by an imperial liberta and a slave in the 1st cent. CE. B. presents the content of several of these tablets (late 1st/early 2nd cent.). With these texts, written in Latin, the victims of injustice requested revenge, addressing their payers to Mater Magna, (p. 673: rogo te, domina Mater Magna, ut tu me vindices; p. 674: Mater deum, tu persequeris per terras per [maria] ...; p. 678: Mater Magna, te rogo p[e]r [t]ua sacra et numen tuum), Attis, who is associated with Castor and Pollux (p. 680: bone sancte Atthis Tyranne, adsi(s), aduenias Liberali iratus; per omnia te rogo, domine, per tuum Castorem, Pollucem, per cistas penetrales), and Attis and Magna Mater (p. 683: in megaro eum rogo te, $M<a>t<e>r$ Magna, megaro tio recipias et Attis, domine, te precor ut bu(n)c (b)ostiam acceptum abiatis; p. 686: sancta Mater Magna ...; tibi commendo, Attibi d<o>omine, ut me uindices). The offences include cheating (p. 673: me fraudavit Ulattius Seuerus; p. 674: quisquis dolum malum adm [isit --] hac pecun [i] a ...; qui pecunia dolum malum adbibet, p. 686: mibi fraudem fecit) and theft of jewelery (p. 678: Gemella fiblas meas qualis sustulit). The victims of injustice wished their opponents to die (p. 672: 'their members should dissolve as this piece of lead dissolves, so that they may die'; p. 680: malum exitum; p. 686: exitum malum), to suffer mental disease (p. 680: des ei malam mentem), to fail in their undertakings (p. 673: omnia quidquid agit, quidquid aginat, omnia illi auersa sint; ut sal et acqua illi eneniat), to experience the mutilation of the Galli (Kybele's followers), the bellonari (the priests of Bellona), and the magali or magili, unknown priests (p. 674: quomodo galli, bellonari, maga[l]i sibi sanguin [em] feruentem fundunt ...; cf. p. 678: quomodo galli se secarunt, p. 686: uti Galli Bellonariue absciderunt conciderunte se), to be excluded from the circle of men (p. 686: p. 686: nec illi in numero hominum sunt, neque ille sit), to lose fortune and reputation (p. 686: sic et illi siccet fama, fides, fortuna, faculitas), and their death to be observed by the people (p. 678: ut exitum tuum populus spectet, of. p. 680: exitum quarum populus spectet). One of the longest texts (p. 674) requests that the culprits confess their crime (et dicat se admisisse ne[fa]s) and promises reward (d[e]mando tibi re[ligione] ut me notis condamnes et ut laetus libens ea tibi referam, si de eo exitum malum faceris); two other texts threaten that their adversaries shall never find redemption (p. 678: nec se possint redimere; p. 680: neque se possit redimere). One text is explicitly designated as a defixio (p. 684: devotum defictum illum membra), another uses the expression in hac tabula depono (p. 686). [These texts are of great significance for the study of ancient magic. They are excellent examples of prayers for justice, a group of texts that $B$. has not considered in his brief report. There are close parallels from Spain and Britain. But, surprisingly, the closest parallels for the confession, are the texts from Knidos that request the adversary to come to the sanctuary and confess his crime (EBGR 1994/95, 362). The promise of reward recalls the ritualised cession of disputed property to gods, which is attested in confession inscriptions and prayers for justice (see EBGR 2004, 44); see also infra no 76.]

16) P. Bonnechère, Trophonios de Lébadée. Cultes et mythes d'une cité béotienne au miroir de la mentalité antique, Leiden, 2003 [BE 2007, 311; SEG LV 555]: Based on the literary and epigraphic sources, B. presents a systematic study of the sanctuary of Trophonios in Lebadeia, the rituals, the oracular consultation (with a list of individuals who are known to have consulted the oracle), and the myths, the festival of the Trophonia, and the cults of Lebadeia. 
17) G.W. Bowersock - C.P. Jones, “A New Inscription from Panticapaeum”, ZPE 156 (2006), p. 117-128 [SEG LV 862]: A fragmentary inscription from Pantikapaion, containing a long funerary oration for an officer in the service of a Bosporan king, was first published by Y.G. VINOGRADOV and S.A. SHESTAKOV (VDI 2005.2, p. 42-44; cf. S.Y. SAPRYKIN, ibid., p. 45-80). B.-J. make this text better known, presenting a new critical edition and avoiding the many rather speculative restorations of the ed. pr. They demonstrate that the anonymous officer had served under Sauromates II (late 2nd cent. CE). The new text (47 lines) is of great interest for the study of the genre of funerary orations. As regards its significance for Greek religion, we mention the designation of the deceased officer as a hero

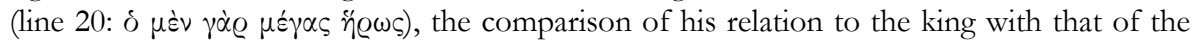

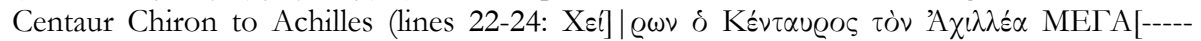

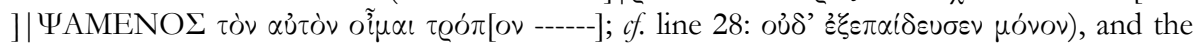
reference to the descent (of the king?) from Poseidon and Herakles (lines 26-27: [aे

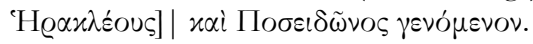

18) C. BRÉLAZ - R. Frei-STOLBA - A.D. RiZAKIS - A.G. ZANIS, "De nouveaux notables dans la colonie de Philippes", BCH 130 (2006), p. 519-547: Ed. pr. of an honorary inscription from Philippi (527-530 no. 2) for a priest of Antoninus (flamen imperatoris Antonini).

19) J. BRemmer, “The Sacrifice of Pregnant Animals”, in Greek Sacrificial Ritual, p. 155-163: B. urges to consider the sacrifice of pregnant animals as part of a 'symbolic system'. Adducing cult regulations from Athens ( $I G \mathrm{I}^{3} 250$ line 30; IG II 949 line 7; SEG XXXIII 147 lines 38 and 44; LSCG 18 E 16-21; 20 B 12 and 48-49; 28 line 16; LSCG Suppl. 19 line 92), Andania (LSCG 65 lines 33 and 68), Rhodes (LSCG Suppl. 95), Mykonos (LSCG 96 lines 15-17), Kos (LSCG 151 B 3; Iscr.Cos ED 241 line 3), Gortyn (LSCG 146), and Miletos (LSAM 41 line 6), he distinguishes between two types of sacrifice of pregnant animals: 1) sacrifice offered to goddesses with 'abnormal cults', such as Demeter Chloe, Ge and Rhea in Athens, and Demeter in Andania, Delos, Mykonos, Kos, Rhodes, and Gortyn; 2) sacrifice offered during the transitional period between youth and adulthood, in connection with the cult of Hera Antheia in Miletos (LSAM 41 line 6), Artemis in Patmos (SGO I 01/21/0), and Athena Skiras in Athens.

20) S. BuyskyKh, "The Beykush Sanctuary of Achilles from the Greek Colonisation Period in the Lower Bug Region", in J. BOUZEK - L. DOMARADZKA (eds.), The Culture of Thracians and their Neighbours. Proceedings of the International Symposium in Memory of Prof. Miecsyslaw Domaradzki, with a Round Table "Archaeological Map of Bulgaria", Oxford, 2005, p. 201-207: Summary of the information provided by graffiti on the cult of Achilles at Bejkuš near Olbia.

21) M.A. Byrne - G. Labarre, Nouvelles inscriptions d'Antioche de Pisidie d'après les Notebooks de W.M. Ramsay, Bonn, 2006 (IGSK 67) [BE 2006, 409]: Ed. pr. of 241 Greek and Latin inscriptions copied between 1882 and 1928 by W.M. Ramsay in Antiocheia in Pisidia, mostly in the sanctuary of Mes Askainos. Cults: The most important cult in Antiocheia was that of

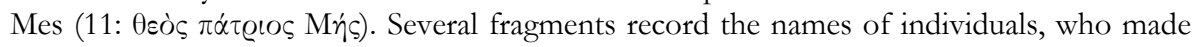

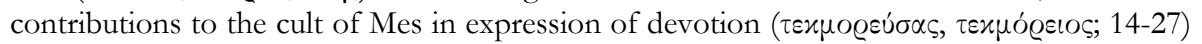
[cf. EBGR 2004, 159 and 166]. The officials of this association of worshippers included $\beta \varrho \alpha \beta \varepsilon v \tau \alpha i$ (16 and 21) and $\pi \varrho \omega \tau \alpha \nu \alpha \lambda \lambda \iota \tau \alpha i$ (16; connected with a ritual banquet) [cf. the

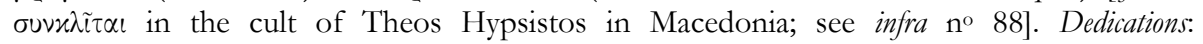
Dedications are addressed to Mes (32-40; nos. 35-37 with the expression $\tau \varepsilon x \mu o \varrho \varepsilon u ́ \sigma \alpha \varsigma)$, Nemesis Epekoos (31), Theoi (28-29), Theos Epekoos (30). A dedication was made by a

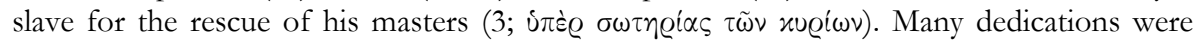

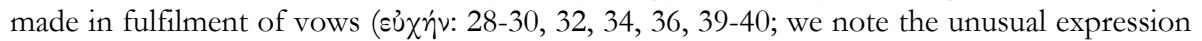




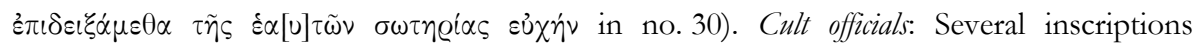
mention priests (41-43, 47b?, 48, 64; cf. 163: sacerdos) and a high priest of Mes for life (11). An inscription, which mentions an augur and priest (9), probably refers to the agonothetes C. Ulpius Baebianus, who also served as augur (12). Festivals-contests: There are several references to the agonothetai of the contest Maximianeia $(8,11)$, one of whom served for life (12); a small fragment records a victory of a boy in the pankration (13). A fragmentary honorary inscription for a benefactor mentions the organisation of gladiatorial combats (169: [munus ve]nation (um) et g[ladiat(orum)). The existence of gladiatorial games is also attested

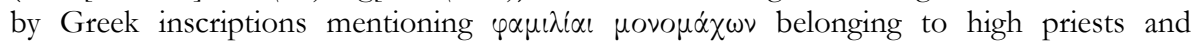
priestesses (M. TAŞLIALAN, "Pisidia Antiokheia's1 1999 yili çalışmaları", in 11. Mų̈̌e çalssmalar ve kurtama kažlari semposyumu, 24-26 Nisan 2000, Denizli, 2001, p. 134-146). Imperial cult: A Latin dedication to Tiberius (147). Foundations: An epitaph mentions Artemis (75). [The eds. suspect that the stele was erected for someone, who exercised a function in the cult of Artemis. But [ $\chi \alpha \tau \hat{\varepsilon} \lambda \varepsilon \iota \pi[--]$ (L. 5) must refer to a bequest of money probably for

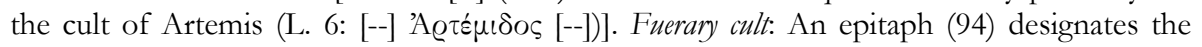

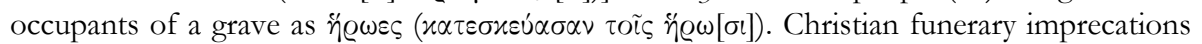

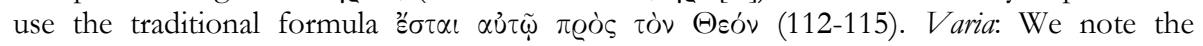
designation of a benefactor as $\pi \varrho \tilde{\omega} \tau 0 \varsigma \tau \tilde{\omega} \nu$ 'E $\lambda \lambda \dot{\eta} \nu \omega \nu$ (2) [an expression used for the winner of the race at the Eleutheria in Plataia].

22) P. CABAnes - J. REBOton - A. Hajdari - S. ShPuZA, "L'expédition épigraphique à Grammata”, BCH 130 (2006), p. 817-821: Ed. pr. of two commemorative, rock-cut inscriptions at Grammata in Illyria. Numerous texts of the $\dot{\mu} \mu \nu \dot{\sigma} \theta \eta$-type were written by sailors and travellers, who attributed the safe end of a dangerous journey to the protection of the Dioskouroi. The first text was inscribed by a Tryphon together with fellow slaves

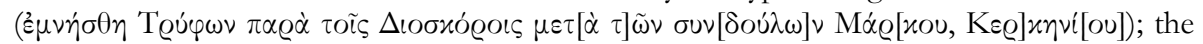

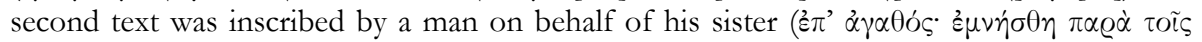

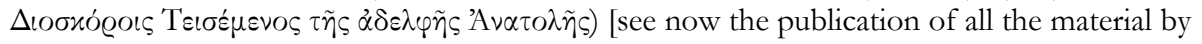
A. HADJARI et al., "Les inscriptions de Grammata (Albanie)", REG 120 (2007), p. 353-394].

23) S. ČAČE - L. ŠEŠELJ, "Finds from the Diomedes' Sanctuary on the Cape Ploča: New contributions to the Discussion about the Hellenistic period on the East Adriatic", in M. SANADER (ed.), Illyrica antiqua ob honorem Duje Rendic-Miočević, Zagreb, 2005, p. 163-186 [BE 2007, 61; SEG LV 658]: The authors mention the discovery of more than 500 fragments of pottery with graffiti in a sanctuary of Diomedes at Punta Planka (promonturium Diomedis) in Dalmatia ( $c f$. EBGR 1999, 128). The graffiti were usually inscribed on drinking vases dedicated to Diomedes by individuals with Greek names. The dedicants were sailors ( $c f$. $\sigma \cup v v \alpha \tilde{u} \tau \alpha l)$, probably from the island of Issa. Three fragments attest the formula

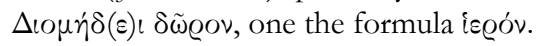

24) É. CAIRON, "Une vie bienheureuse dans l'au-delà. L'épigramme pour Protê, IGUR, 3, no 1146", REG 119 (2006), p. 776-781: C. republishes the funerary epigram for Prote, who died at the age of seven, set up by her father (Rome, 3rd cent. CE). The great interest of this epigram lies in the fact that it presents a very detailed description of the afterlife and the underworld: 'Prote, you have not died; you are gone to a better place and you live in the islands of the blessed, in great abundance; there, in the Elysian plain, you rejoice leaping among the delicate flowers, away from all evil. Neither winter nor heat bring you sorrow; illness does not disturb you; you know neither hunger nor thirst. But you also have no longing for the life of humans. For you live blameless in pure light, indeed close to Olympus'. C. provides literary and some epigraphic parallels for this image of afterlife. 
25) C.B. Champion, "In Defence of Hellas: The Antigonid Soteria and Paneia at Delos and the Aetolian Soteria at Delphi”, AJAH NS 3/4 (2004/05) [2007], p. 72-88: C. argues that Antigonos Gonatas responded to the announcement of the Aitolian Soteria in Delphi in 246 BCE by establishing the festivals Soteria and Paneia in Delos in 245 BCE. These festivals commemorated his victory over the Gauls in $278 / 7$, not his more recent naval victory over a Ptolemaic fleet.

26) A. CHAniotis, "Familiensache: Demonstration von Zusammengehörigkeit im altgriechischen Grabritual", in R. REICHMAN (ed.), "Der Odem des Menschen ist eine Leichte des Herrn". Aharon Agus zum Gedenken, Heidelberg, 2006, p. 205-209: C. discusses expressions of emotionality in funerary rituals: the mention of the fact that a family member or a friend was personally involved in the burial in grave inscriptions (SGO I 01/12/17; 02/03/01; IV $17 / 16 / 01 ; 18 / 01 / 23 ; 22 / 37 / 01)$; the touching of the corpse, stressed in some funerary epigrams (SGO I 02/09/34; 05/01/46; II 08/05/06; 09/05/14; 09/12/04; 10/01/01; $10 / 05 / 02$; IV 22/37/01); and the interruption of a family burial by the people, the

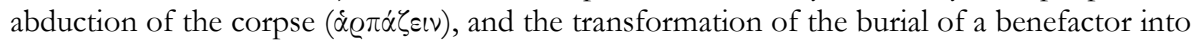
a public burial (I.Knidos 71; SEG XLV 1502; L 1109; Philostratos, Vitae sophist. XV 20; cf. EBGR 2000, 91). Normative interventions attempted to limit the circle of those who were polluted by coming into contact with the corpse to the closest family members. In private monuments, emphatic mention of physical contact with the corpse in the relevant sources aimed at demonstrating emotional connection with a family member; the transformation of the burial of a benefactor to a public funeral aimed at creating the illusion that the benefactor and the people constituted a virtual family.

27) D. Clay, Archilochos Heros. The Cult of Poets in the Greek Polis, Washington, DC, 2005 [SEG LV 292, 562-564, 890, 910, 912, 940-941, 956, 973, 1126, 1269, 1273, 1276, 1334, 2051]: Based on an exhaustive collection of the relevant literary, epigraphic, and archaeological evidence, C. presents a thorough study of the cult of poets and posthumous honours awarded to them. The largest part of the book is dedicated to the best known cult, that of Archilochos in Paros (9-62, 104-124: SEG XV 517; IG XII 5, 445). The evidence for the cult of Homer is also collected (p. 136-143), especially in Ios (142: IG XII 5, 15), Chios (140f.: Kaibel, EG 860; SEG XXX 1073), possibly Delos (Homereion: I.Délos 443 Bb 147, 178 BCE; p. 141), Notion (142: Homereion), Pergamon (88f. and 137f.: I.Pergamon 203), and Alexandria [for Delos, see EBGR 2003, 49. In the case of Chios, according to a restoration of SEG XXX 1073 lines 34-36 (A. CHANIOTIS, Historie und Historiker in den griechischen

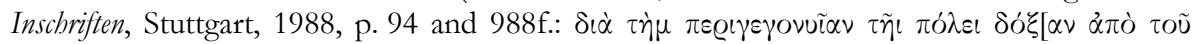

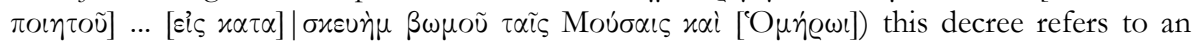
altar for the worship of the Muses and Homer]. Other poets discussed by C. include Pindar (p. 78: IG II ${ }^{2} 8883=G V$ 894), Sophocles, worshipped as Dexion in Athens (p. 78f. and 151: IG II ${ }^{2}$ 1252-1253), Poseidippos of Kassandreia (p. 150: IG II 1320 LL. 14/15; 1331; I.Délos 2486), Poseidippos of Pella (p. 84-86 and 150: SEG XLII 691 b), Arideiktes or Rhodes (86f. and 129f.: GVI 1451), Antigonos of Knidos (p. 84 and 129/130. I.Knidos 301). Clay also discusses the cult of Bias of Priene (131f.: I.Priene 111, 113, and 117), the Mouseion founded by Epikteta on Thera (72-74: IG XII 3, 330) and the cult of the athlete Theogenes in Thasos (p. 69-71 and 125f.: LSCG Suppl. 72). Following P. Roesch, C. suspects that a list of members of a cult association in Thespiai (SEG XXXII 503; c. 400350; pp. 87 and 153) is connected with the cult of the poet Thamyris (cf. line 2:

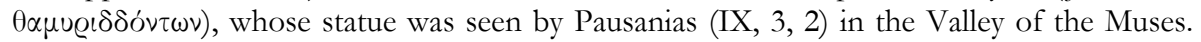
[This is improbable. A cult association of worshippers of Thamyris would be called

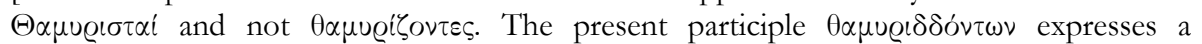
temporary function ( $c f$. $i \alpha[\varrho] \alpha \varrho \chi^{i o v \tau o \varsigma}$ and $\left.\dot{\alpha} \gamma \iota \mu \varepsilon^{\varepsilon} v \omega v\right)$ and not a cult. Only two members of 


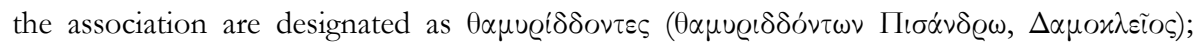

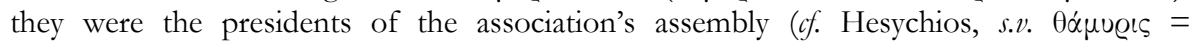
assembly)]. The boundary stone of the land of a cult association of worshippers of the Muses in Thespiai (IG VII 1785, late 3rd cent.) is probably not connected with a cult of

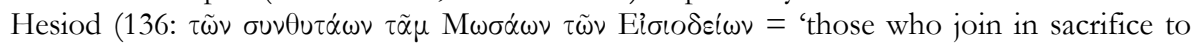
the Muses of Hesiod') [cf. EBGR 2004, 17].

28) K. Clinton, "Pigs in Greek Rituals", in Greek Sacrificial Ritual, p. 167-179 [SEG LV 2091]: Making ample use of cult regulations, C. distinguishes between two separate functions of pigs, piglets, and pregnant sows in Greek sacrificial ritual. When sacrificed at the Thesmophoria, pigs were deposited in pits in order to promote fertility; only this type of sacrifice can be designated as 'chthonian'. Pigs were often used in purifications of places (e.g. Kos: LSCG 156 A 13-20; Athens: IG II² 1672; Delos: IG XI 2, 146 A and 199 A; I.Délos 338; Andania: IG V 1, 1390; Erythrai: I.Erythrai 207 = LSAM 26); in this case, they were not carried around the place, with their blood dripping, but instead they were entirely burned on an altar. In the case of a cult regulation from Erythrai, which mentions a sacrifice to the ö $\pi \sigma \theta \varepsilon \theta \varepsilon \alpha i$, C. tentatively identifies these goddesses as wrathful spirits. The sacrifice of a pig in the Selinuntian regulation concerning purifications (SEG XLIII 630) is a normal sacrifice (not a purificatory one), marking the purificand's re-entry into normal life.

29) F. Costabile, "Defixiones dal Kerameikós di Atene", MEP 9/10 (2004/05), p. 137-192 [SEG LIV 395-399]: Ed. pr. of three curse tablets from Kerameikos in Athens. 1) A curse

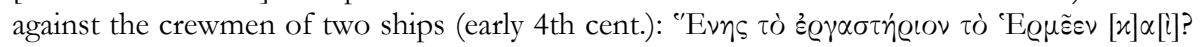

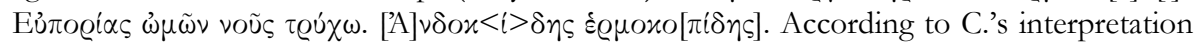

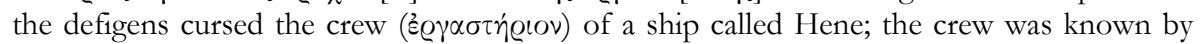
the nickname Hermes. He also cursed the cruel mind of the crew of another ship, called Euporia; both ships belonged to the famous orator Andokides. 2) A fragmentary defixio

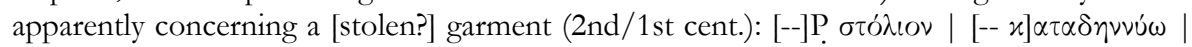

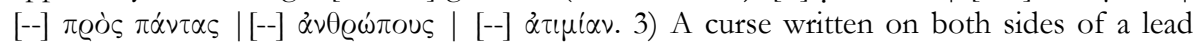
tablet (c. 400-375); on one side, the formula $\tau \dot{\alpha} \varsigma \gamma \lambda \dot{\omega} \tau \alpha \varsigma \tau o \dot{\tau} \tau \omega \nu x \alpha \tau \alpha \delta \tilde{\omega}$ is used (which implies a judicial defixio); on the other side a curse is addressed $(x \alpha \tau \alpha<\alpha>\delta \tilde{\omega})$ against

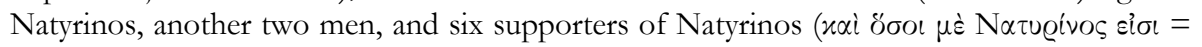

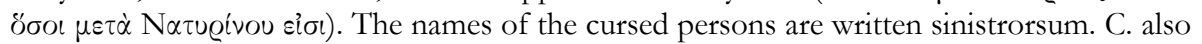
presents improved editions of two other curse tablets. 4) SEG XXX 325(2): a defixio addressed against the supporters of the pro-Macedonian statesmen in Athens (ca. 317-307). C. argues that the name of Eunomos of Peiraeus (L. 6) was added later by a different hand: 5) In SEG XLIX 314 (late 5th cent.), we note here the restoration ė $\pi \dot{\eta} \lambda u[\theta o v ?]$ (aorist of

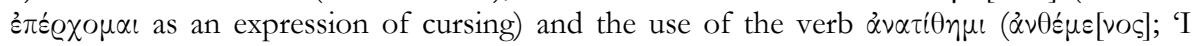
consecrate (to the chthonic gods)'.

30) M.-T. Couilloud-Le DinaheT, "Les rituels funéraires en Asie Mineure et en Syrie à l'époque hellénistique (jusqu'au milieu du Ier siècle av. J.-C.)", Pallas 62 (2003), p. 65-95: Making ample use of the relevant inscriptions, the author gives a very good overview of funerary practices in Hellenistic Asia Minor and Syria, discussing inter alia the graves of members of the elite; funerary monuments for fallen warriors; public funerals; the heroization of the dead; and the protection of the graves.

31) O. CURTY, "Un usage fort controversé : la parenté dans le langage diplomatique de l'époque hellénistique", AncSoc 35 (2005) 101-117 [BE 2006, 136]: The significance of the

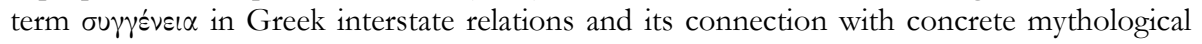
narratives have been the subject of a controversy (see EBGR 1997, 403). Recently, S. LÜCKE, Syngeneia. Epigraphisch-historische Studien zu einem Phänomen der antiken griechischen Diplomatie, 


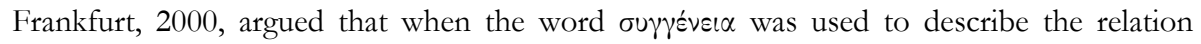
between cities and peoples, it did not have its usual meaning of a 'blood relationship', but a broad and metaphorical meaning. Based on a close analysis of this term in inscriptions and literary sources (with emphasis on the relations of Priene with Athens and Boiotia), C.

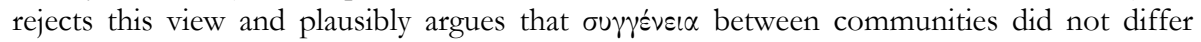

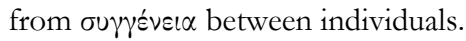

32) G.B. D’Alessio, "Some Notes on the Salmakis Inscription", in The Salmakis Inscription, p. 43-57: D. comments on the metrical inscription from Halikarnassos (cf. infra nos. 64-66). We single out his comments on the cult of Aphrodite Schoinis ('Aphrodite of the Reeds', possibly related to the Samian cult of Aphrodite; see Lykophron, Alex., 832), on the myth of Zeus' birth, and on Hermaphroditos.

33) P. Debord, "Le culte royal chez les Séleucides", Pallas 62 (2003), p. 281-308: D. gives an overview of the cult of the Seleucids kings by the army and the cities, and the cult which was centrally organized by the dynasty, with particular reference to the cult of Antiochos III in Sardeis, Teos, Amyzon, and Xanthos, and to the relations of the Seleucids to Zeus. D. discusses the copies of Antiochos' III letters, which concern the establishment of the office of the archiereus.

34) M.P. DE HOZ, "Inscripciones griegas de Oriente introducidas en España por el comercio de antiguedades", ZPE 155 (2006), p. 145-149 [BE 2006, 381]: The author discusses an epitaph dedicated by Sortias to his daughter and his sister (SEG XXXVIII

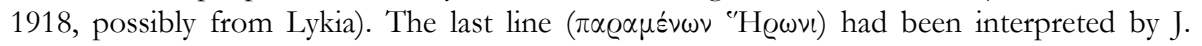
Nieto Ibáñez as a reference to the institution of paramone. Instead, de Hoz proposes the

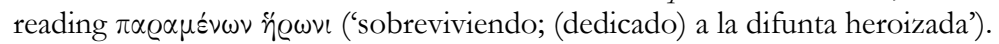

35) M.P. DE Hoz, "Literacy in Rural Anatolia: The Testimony of the Confession Inscriptions", ZPE 155 (2006), p. 139-144 [BE 2006, 352]: After summarizing the character and content of the 'confession inscriptions', de Hoz stresses the importance of the written narrative of divine punishment ( $\mu \alpha \varrho \tau \cup \varrho \varepsilon ́ \omega, \mu \alpha \varrho \tau u ́ \varrho ı v)$ as an expression of piety. She argues that deviations from standard language in these texts may be indications that the texts were written by the worshippers, not the priests. Consequently, these texts provide valuable evidence for literacy.

36) N. Deshours, Les mystères d'Andania. Étude d'épigraphie et d'histoire religieuses, Bordeaux, 2006 [BE 2007, 301]: D. presents a critical edition, translation (p. 27-46) [cf. infra no. 98], and exhaustive commentary of the cult regulation of the mysteries of Andania (IG V 1, 1390; LSCG 65) [on the date (24 CE and not 91/90 BCE) see now EBGR 2004, 268; but $c$. the doubts of S. MiNON and L. DuBOIS, BE 2007, 301]. She discusses the measures taken by Mnasistratos and the city of Messene for the re-organisation of the cult (p. 65-97), the regulations concerning order in the sanctuary, supplication, the punishment of crimes committed during the festival (99-114), and the various aspects of the celebration (oaths, procession, sacrifices, the rites of the mysteries; 115-137). A large part of the book is dedicated to a close study of Pausanias and other sources for a reconstruction of the religious history of Messene (the question whether there were cults of the belotes and the perioikoi, possible Spartan influences), the significance of religious traditions and legends for the development of a Messenian identity, and the development of the mysteries in the Imperial period. Among D.'s contributions to the interpretation of the mysteries of Andania, we single out her view that the cult regulation marked the restoration of an early cult, the identification of the Great Gods in the Karneasion with the Dioskouroi, the study 
of the prominent part played by Demeter in this cult, and the distinction between the mysteries in the sanctuary called Karneiasion and the festival of the Karneia.

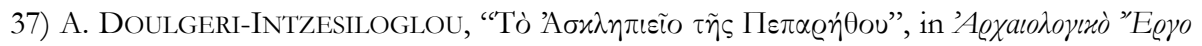

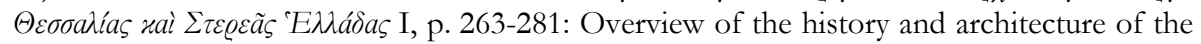
sanctuary of Asklepios (and Apollo?) at Peparethos (Skopelos). The finds include a dedication to Asklepios.

38) B. Dreyer - H. Engelmann, "Augustus und Germanicus im ionischen Metropolis", ZPE 158 (2006), p. 173-182 [BE 2007, 446]: Ed. pr. of several important inscriptions from Metropolis. Three altars found in the theatre are connected with the Imperial cult (p. 173175). One of the altars is dedicated to Augustus, the other two are designated as altars for

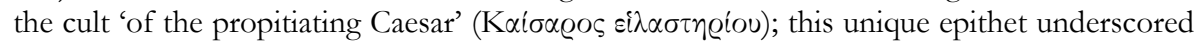
Augustus' achievement in establishing peace. Another altar, also from the theatre, is dedicated to Germanicus Iulius Caesar by a priest (of Germanicus) [this is not unequivocally stated in the text]; the altar is designated as $\ddot{\alpha} \sigma u \lambda \circ \varsigma$, i.e. it could be used by suppliants (c. 4-19 CE; p. 174f.). The most important inscription contains excerpts of the famous dossier concerning the introduction of the Julian calendar in the province of Asia (p. 175-182, 9 BCE); copies of the relevant documents have been found in Priene and Apameia. The inscription begins with the edict of the governor Paulus Fabius Maximus concerning the celebration of Augustus' birthday (lines 1-35); the decree of the Koinon of Asia follows (lines 36-51). The new copy makes the restoration of several passages possible, especially

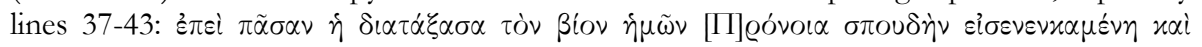

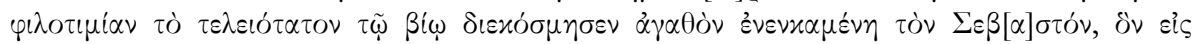

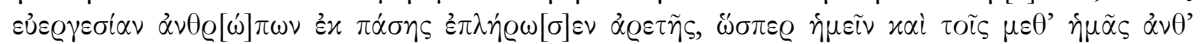

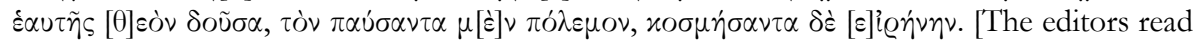

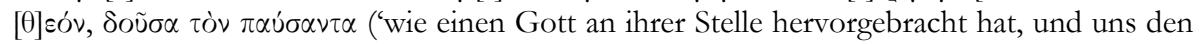

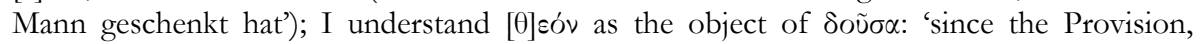
which has ordered our life, has shown every zeal and fervour and has provided the most perfect good for our life by bringing Augustus, whom she has filled with every virtue, so that he can be a benefactor to men, and has given him to us and to our descendants as a god, to represent her, the one who has put war to an end and has adorned the peace'; as the editors point out, divine provision sent Augustus to the world as her representative.] Also the passage concerning Augustus' birthday can now be restored: $\tilde{\eta} \varrho \xi \varepsilon \nu ~ \delta \varepsilon े ~ \tau \tilde{\varphi}$ xó $\sigma \mu \omega \tau \tilde{\omega} \nu \delta$ '

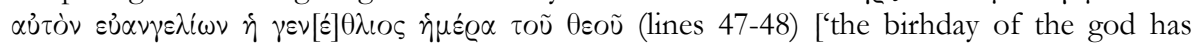
marked for the world the beginning of the the good tidings, which he has brought forth'].

39) P. Ducrey - C. Calame, "Notes de sculpture et d'épigraphie en Béotie. II. Une base de statue portant la signature de Lysippe de Sicyone à Thèbes", BCH 130 (2006), p. 63-81: Ed. pr. of the inscribed base of a bronze statue made by Lysippos [already mentioned in EBGR 1999, 63]; it was found in Boiotia, but the exact provenance is unknown (c. 372-364 BCE). According to an honorary epigram, the statue was dedicated by Hippias to Zeus Saotas. It represented a military commander (probably the dedicant himself), who increased the glory of Thebes. The cult of Zeus Saotas is known in Thespiai (Paus. IX, 26, 7-8), where this statue may have been dedicated.

40) C. DuRvye, “Aphrodite à Délos : culte privé et public à l'époque hellénistique”, REG 119 (2006), p. 83-113 [BE 2007, 22]: D. reconstructs the development of the cult of Aphrodite on Delos from the 4th to the 1 st cent. In addition to the public cult of Aphrodite, attested through references to dedications and to the festival of the Aphrodisia in the Delian accounts and inventories, in the late 4th cent. Stesileos founded a private sanctuary, which was under the care of members of his family until the 2 nd cent.; the cult of 
Aphrodite was connected with two commemorative festivals established by Stesileos in 302 BCE and by his daughter Echenike in 250 BCE (Stesileia and Echenikeia). D. argues that the foundation of the sanctuary was connected with private piety and self-staging of a family. The Delian accounts and inventories provide information concerning the cult statue, the altar, and the temple (cf. I.Délos 1417 A II lines 1-21). In the period of Athenian domination (after $167 \mathrm{BCE}$ ), in which foreign cults became public cults, the sanctuary lost its semi-private character and came under the supervision of the Athenian authorities $(c f$. I.Délos 1810-1811).

41) E. EIDINOw, "An Inscription in the Basement of the Ashmolean Museum, Oxford", ZPE 156 (2006), p. 113-116: Ed. pr. of a fragmentary inscription, a dedication to Apollon or a boundary stone of a sanctuary of Apollon, probably from Naukratis (late 6th/early 5th cent.), now in the Ashmolean Museum in Oxford.

42) H. EngELmanN, “Zur Lykiarchie”, ZPE 158 (2006), p. 183-186 [BE 2007, 467]: Ed. pr. of an honorary inscription for the high priest of the Sebastoi in Lykia and secretary of the Lykian Koinon M. Aurelius Dionysios, a descendant of Lykiarchs (Patara, early 3rd cent. CE). The great significance of this text rests in the formulation ė $\pi i$ in $[\pi \varrho o ̀ \varsigma \tau] \dot{\eta} \nu \Lambda u x\left\llcorner\varrho \chi^{i \alpha \nu}\right.$ $\varphi \iota \lambda \circ[\tau] \iota \mu i \alpha$. The high priest is honoured for his good conduct as a Lykiarches. This settles once and for all the question whether archiereus and Lykiarches were separate functions [cf. EBGR 2005, 53; M. Zimmermann, "Die Archiereis des lykischen Bundes. Prosopographische Überlegunen zu den Kaiserpriestern", in C. SCHULER (ed.), Griechische Epigraphik in Lykien. Eine Zwischenbilanz: Akten des Int. Koloquiums, München, 24.-26. Februar 2005, Vienna, 2007, p. 111-120]. They were not. The term Lykiarches comprised all the different functions of the president of the Koinon, i.e. his function as a high priest and his function in the administration of the Koinon (grammateus). In the same article E. republishes a dedication of Dionysios, after the end of his term as Lykiarches, to Theos Hypsistos, Meter Oreia, Kele[- -] (Kelenaios Theos?), and all the gods and goddesses in expression of his gratitude (Neisa; TAM II 3, 737).

43) F. Eraslan - M. Facella - E. Winter, "Neue Funde im Museum Adiyaman aus der Nekropole von Perrhe (Pirun)", AST 23.1 (2005) [2006], p. 57-62: Ed. pr. of a relief dedicated by a soldier in fulfilment of an oracle; it depicts Zeus Dolichenos in military attire

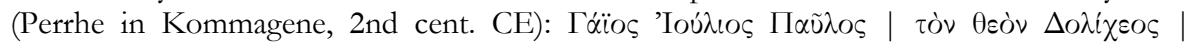

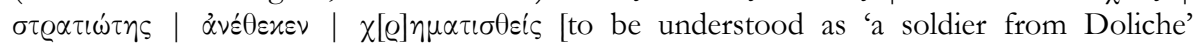

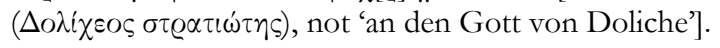

44) A. Fennet, "Sanctuaires marins du canal d'Otrante", in E. Deniaux (ed.), Le canal d'Otrante et la Méditerranée antique et médiévale. Colloque organisé à l'Université de Paris X-Nanterre (20-21 novembre 2000), Bari, 2005, p. 39-49: Overview of the cults of deities, who were regarded as patrons of seafarers in the straits of Otranto: Zeus in the cave Porcinara near Leuke; Zeus Kassios in Kassope on Korkyra; Aphrodite and Eros at Orikos (Illyria).

45) C. FEYEL, Les artisans dans les sanctuaires grecs aux époques classique et hellénistique à travers la documentation financière en Grèce, Athens-Paris, 2006 [BE 2007, 171]: Based on a detailed, comparative analysis of the accounts concerning building activities in five important sanctuaries (the Erechtheion on the Athenian Acropolis, Eleusis, Delphi, Epidauros, and Delos), F. presents a reliable, differentiated, reconstruction of the socio-economic position of craftsmen and the organisation of large construction works from the late fifth to the second century BCE [for the Eleusinian accounts see now K. CLINTON, Eleusis. The Inscriptions on Stone, Athens, 2005, esp. p. 163-169 no. 159 and 188-206 no. 177]. We single out the discussion of the relationship between craftsmen, entrepreneurs, and administrators 
(p. 439-521), which is relevant for the study of Greek sanctuaries. F. points out that the different administrative structure of the sanctuaries affected the planning of building activities, as only the Delian bieropoioi had substantial flexibility in their budget. F. discusses the mixed and distant geographical origin of artisans working in Delphi, Epidauros, and Delos, as opposed to the primarily local recruitment for the Athenian projects (p. 341-368), the different degrees of specialisation, and the significant differences in wages and salaries.

46) J. FourniER, "La société thasienne et l'Empire sous les Julio-Claudiens : deux inscriptions inédites", BCH 130 (2006), p. 499-518: Ed. pr. of a dedication made by the

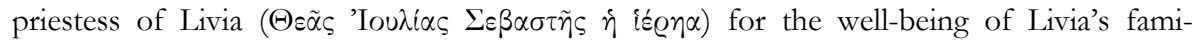

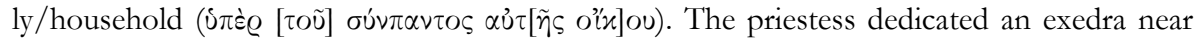
the agora (Thasos, c. 14-29 CE).

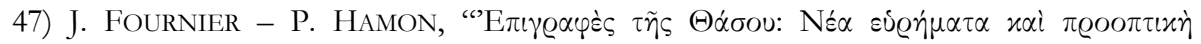

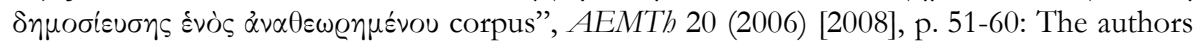
report the discovery of two important texts (Thasos, early 4th cent.). The first inscription is a fragment of the Thasian decree concerning public funerals and honours for the war-dead (LSCG Suppl. 64). The clauses in the new fragment provide for support offered to those orphans of the war-dead who were in need, as well as for honours for non-citizens (metics and others), who had died in war, and privileges for their sons. The second text is an honorary inscription for a benefactor, who had funded the restoration of a sanctuary (of Artemis?) in the late Hellenistic or early Imperial period [now published; see infra $n^{\circ} 48$ ].

48) J. Fournier - C. PrÊTRE, "Un mécène au service d'une déesse thasienne: décret pour Stilbôn”, BCH 130 (2006), p. 487-497: Ed. pr. of a decree of Thasos concerning a donation by Stilbon. Along with his wife Stilbon offered to cover the expenses for the restoration of buildings and the construction of additional buildings in the sanctuary of a goddess (probably Artemis) in order to honour her ([--] $\tau \tilde{\eta} \varsigma \theta \varepsilon \tilde{\alpha} \varsigma \tau \iota \mu \eta \dot{\eta} \nu,[\dot{\alpha} \nu \alpha \delta \varepsilon \dot{\varepsilon} \chi \varepsilon \tau \alpha] \tau \dot{\alpha} \tau \varepsilon \delta \varepsilon \dot{\alpha}_{\mu \varepsilon v \alpha}$

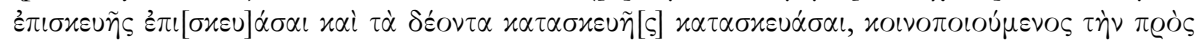

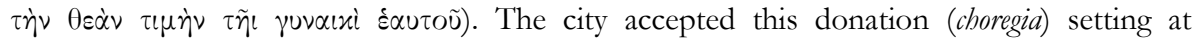
Stilbon's disposal the public slaves (Thasos, mid-1st cent. CE).

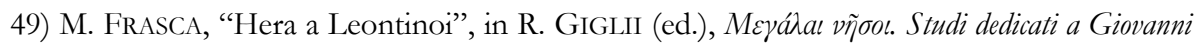
Rizza per il suo ottantesimo compleanno II, Catania, 2005, p. 137-145: A sanctuary excavated in Leontinoi may be attributed to Hera. It was established in the 7th cent.; a monumental altar was built in the second half of the 6th cent.; the sanctuary was destroyed in the eartly 5 th cent. B.C. The finds include vases with graffiti with the letters $h \eta$ and a sima with the text

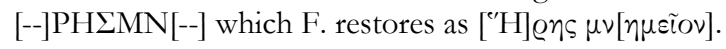

50) P.-L. GATIER - P. LOMBARD - K. M. AL-Sindi, "Greek Inscriptions from Bahrain”, Arabian Archaeology and Epigraphy 13.2 (2002), p. 223-233 [SEG LII 1736-1737]: Ed. pr. of two dedications from Tylos (Bahrain) [now in I.Estremo Oriente 427 and 431]. The governor of Tylos and the islands dedicated a temple to the Dioskouroi Soteres on behalf of the king of Charakene (1; c. 129-124). Another dedication was made in fulfilment of a vow of a sailor or sailors after safe return from a sea voyage (4; 1 st cent.).

51) P. Gauthier, "Les décrets de Colophon-sur-mer en l'honneur des Attalides Athènaios et Philètairos", REG 119 (2006), p. 473-503: G. presents a improved edition of the decree of Kolophon by the Sea (c. 180-160) in honour of Athenaios, the youngest son of Attalos I (p. 474-494; M. Holleaux, Études d'épigraphie et d'histoire grecques II, Paris, 1938, p. 51-60). According to the decree, Athenaios' statue was to be placed in the sanctuary of Apollon Klarios, near the statue of queen Apollonis and his brothers. His cult was established in the gymnasion. The annually elected gymnasiarchos was to perform a sacrifice and organize a race 
of the young men and ephebes in the Homereion (the gymnasion of Kolophon) on Athenaios' birthday; a race of the boys was to take place on the same day in the Homereion, until a palaistra for the boys was built, under the supervision of the paidonomos. The decree contains detailed provisions about the distribution of the meat of the sacrificial animal. A portion was preserved as $\tilde{\alpha} \theta \lambda \alpha$ for the winners in the race (in addition to other prizes, which might be decided in the future). The rest was distributed by the gymnasiarchos to the $\dot{\alpha} \lambda \varepsilon \iota \psi \dot{\alpha} \mu \varepsilon v o$ (those who had participated in the contests or those who had exercised in the gymnasion?), the council, the magistrates, the priests, the prytanis, the prophetes, the sacred council, the winners of staphanitai contests, the hierokeryx, and the scribes. G. discusses in detail the contests that took place in the gymnasion.

52) S. GiannobiLe, "Filatterio contro il mal di testa nella tomba di Iulia", JAC 48/49 (2005/06), p. 54-67: Ed. pr. of an inscribed gold lamina found near Forum Fulvii (early 2nd

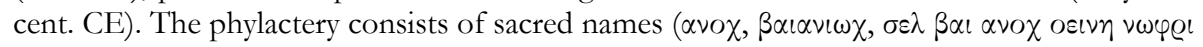
$\alpha \nu \circ \chi \eta x \alpha \varrho \alpha \nu \sigma \chi \sigma \varepsilon x \circ \cup \theta \mu \omega \sigma \varepsilon$ [.] $x о \omega \varphi \varrho \iota \varsigma)$ followed by an invocation aiming at stopping the

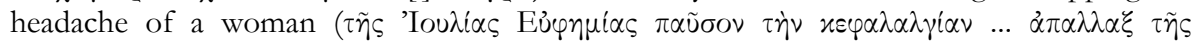

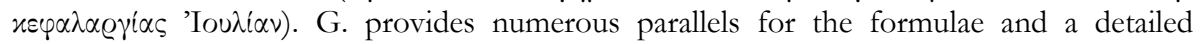
discussion of the use of phylacteries for the healing of headaches.

53) Gorny \& Mosch. Giessener Münzhandlung. Auktion 150. Kunst der Antike. 11. Juli 2006, Munich, 2006: This auction catalogue contains several inscriptions of a religious interest, but unfortunately, of unknown provenance [W. Günther, who has sent us xeroxes of the catalogue, has read the texts]. A bronze statuette (c. 500 BC) of a young man [a victorious athlete?] is inscribed on the right-hand side with the dedicatory inscription Aeyoגixò $\alpha^{2} \varepsilon^{\prime} \theta \varepsilon \varkappa \varepsilon$ (p. 23 no. 18). Two dedicatory reliefs [certainly from Asia Minor] are inscribed. One of them shows two worshippers and a servant approaching a seated goddess (Kybele); under

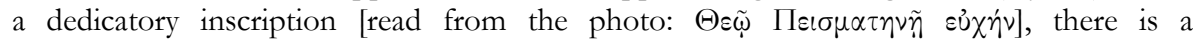
representation of a rider and a bull (p. 115 no. 306). The second relief depicts Zeus with a libation bowl and Apollon Kitharodos (p. 115 no. 307). [Read from the photo: [Mévavo@os

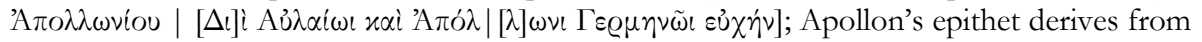
Germe in Mysia; see EBGR 1997, 365.] A grave inscription, inscribed on the base of a bust of a woman [not a man, as erroneously stated in the catalogue. Part of the inscription can be

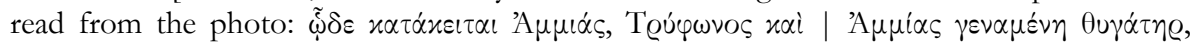

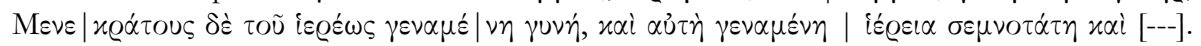
Ammias, daughter of Tryphon and Ammia, was wife of the priest Menekrates and a priestess herself]. A magical gem with the typical representation of Abrasax is inscribed with the magical names ' $\mathrm{\alpha} \omega,{ }^{\prime} \mathrm{A} \beta \varrho \alpha \sigma \alpha \xi \xi$ (p. 103 no. 278). Three other gems are inscribed with

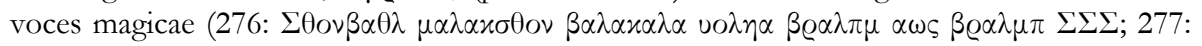

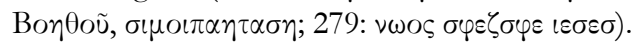

54) Y. GRAndjeAn - F. SAlviat, "Règlements du Délion de Thasos", BCH 130 (2006), p. 293-327: Ed. pr. of a stele from Thasos, which contains two decrees concerning cult regulations (early 4th cent.). The first decree prevents women from entering the sanctuary of

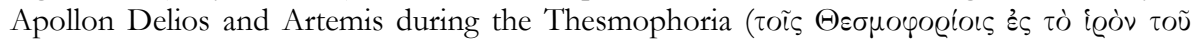

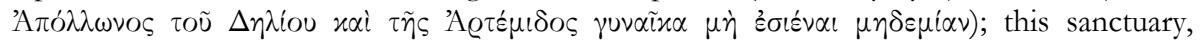
excavated in 2003, is located near the Thesmophorion. The hieropoios of Apollon - a hitherto unattested official - was responsible for closing the sanctuary during the Thesmophoria

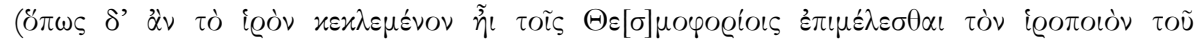

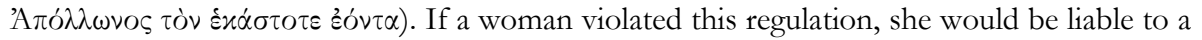

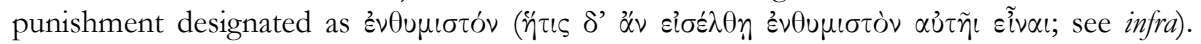
This regulation aimed at keeping good order during the Thesmophoria. The second decree 
orders the publication of an earlier decree prohibiting women from creating enclosures

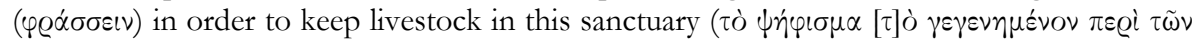

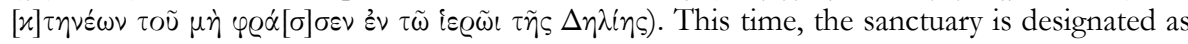
the 'sanctuary of the Delian goddess', i.e. Artemis, who was the primary deity. Obviously, this sanctuary owned land and sacred groves. The editors give a detailed discussion of cult regulations prohibiting the keeping of livestock in sanctuaries. The expenses for the publication were to be paid by the hieromnemon. The new decree also made an addition to the

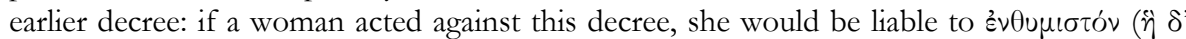

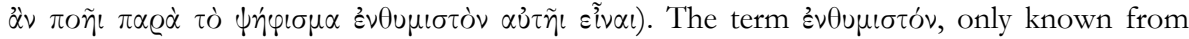
Thasos (LSCG Suppl. 64 and 72), designates a religious punishment, which cannot be determined with certainty; it seems to designate moral condemnation and bad conscience ( $c$.

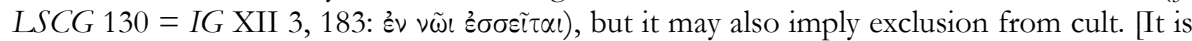
interesting to note that the violations of these decrees by women did not result in the payment of a fine, but in religious punishment. Was this done in order to avoid a financial liability on their kyrios or because the threat of religious punishment appeared more effective?]. G.-S. give an overview of the diffusion of the cult of the 'Delian gods' in the Aegean. The cult of Apollon Delios and Artemis Delia was introduced to Thasos from Paros.

55) A. Greaves, “The Cult of Aphrodite in Miletos and its Colonies”, AS 54 (2004), p. $27-$ 34: Collection of the predominantly epigraphic evidence for the cult of Aphrodite in Miletos and its colonies (Histria, Olbia, Kepoi, Prokonnesos, Naukratis, the cities of the Bosporan Kingdom).

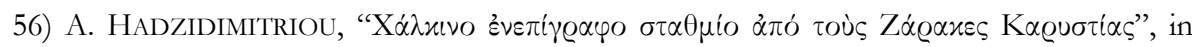
'Aexaı with a ram head in relief on top and a pointed inscription ('A $\pi$ ó $\lambda \lambda \omega \nu \circ \varsigma \Delta \eta \lambda i o$ ) along its sides (Zarex, Euboia, 4th cent.). H. discusses the use of the ram as a symbol and the role played by Zarex on the route of the Hyperborean offerings to Delos ( $c$. Herodotos, IV, 33).

57) P. Hamon, "Un prêtre des dieux boulaioi dans le bâtiment du Conseil de Cos", Chiron 36 (2006), p. 151-168: H. presents a new edition of a Koan fragmentary inscription (IscrCos ED 32), which he identifies as a regulation concerning the sale of the priesthood of the gods whorshipped by the council. According to his restoration, the text refers to the cult of the gods (line 5: $[\tau \dot{\alpha} \nu \theta] \varepsilon \varrho \alpha \pi \varepsilon i \omega \nu \tau \tilde{\omega} \nu \theta \varepsilon \tilde{\omega} \nu$ ), the performance of sacrifices, the right of the priest to wear a (gold) crown on festive days and receive an honorary portion from sacrifices (lines

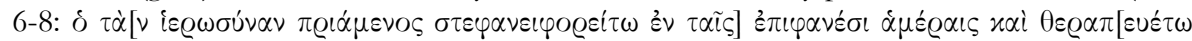

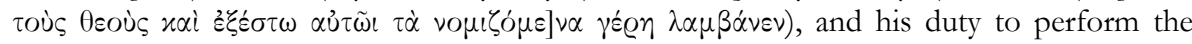

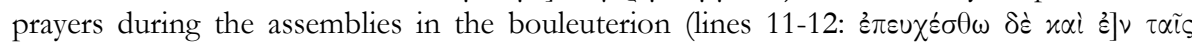

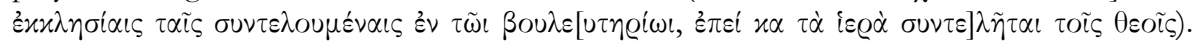
One tenth of the price for this priesthood was to be spent on the decoration of the statues

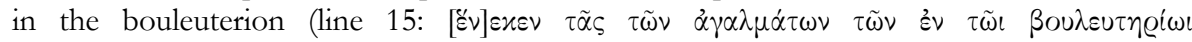

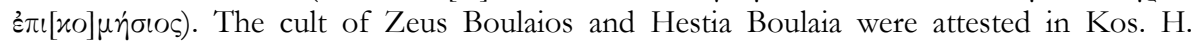
briefly comments on the cults of the council in the Hellenistic period.

58) H. Harrauer, “Ein Spendengefäss für Triphis”, in F. BeutLer - W. Hameter (eds.), "Eine gan₹ normale Inschrift" ... und ähnliches zum Geburtstag von Ekkehard Weber. Festschrift zum 30. April 2005, Vienna, 2005, p. 289-292: Ed. pr. of a dedication inscribed on an alabaster vase used for libations; Tachratis dedicated the vase to Thriphis, $\theta \varepsilon \dot{\alpha} \mu \varepsilon \gamma i \sigma \tau \eta$ (Egypt, 9 CE).

59) B. Helly, "Décret de Larisa pour Bombos, fils d'Alkaios, et pour Leukios, fils de Nikasias, citoyens d'Alexandrie de Troade (ca 150 av. J.-C.)", Chiron 36 (2006), p. 171-203: H. republishes an important honorary decree for Bombos of Alexandreia Troas, a historian 
or orator, who visited Larisa in c. 150 BCE. In his public lectures in the gymnasion, Bombos 'commemorated both in his treatises and in his lectures the glorious events that have occurred with regard to the Lariseans and renewed the kinship and the friendship between

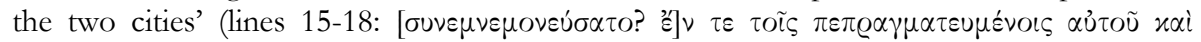

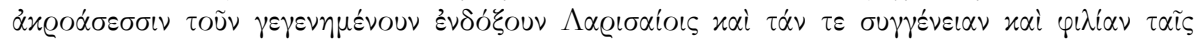

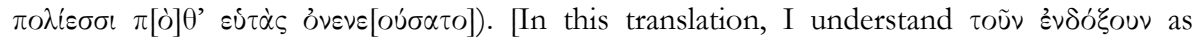
neuter (glorious deeds); Helly (p. 173 and 198) who translates 'des personnages qui ont été

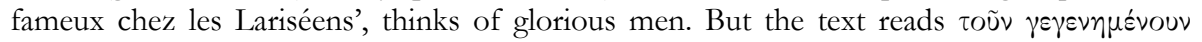

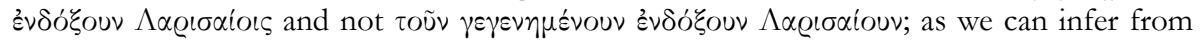
parallels, Bombos probably treated wars, foundation myths, and miracles of local gods; see A. Chaniotis, "Travelling Memories in the Hellenistic World", in R. Hunter - I. Rutherford (eds), Wandering Poets in Ancient Greek Culture: Travel, Locality, and Panhellenism, Cambridge, 2009, p. 249-269]. This decree was published in the sanctuary of Apollon Kerdoios (line 31).

60) A. Henrichs, "'Sacrifice as to the Immortals'. Modern Classifications of Animal Sacrifice and Ritual Distinctions in the Lex Sacra from Selinous", in Greek Sacrificial Ritual, p. 47-58: H. tests the validity of modern classifications of sacrifice ('blood ritual' vs. 'fire ritual', 'Speiseopfer' vs. 'Vernichtungsopfer', 'Olympian' vs. 'chthonian', 'marked' vs. 'unmarked', 'divine' vs. 'heroic') through a study of the clauses concerning sacrifice in the cult regulation of Selinous concerning purification. He notes the juxtaposition of sacrifices 'as to the gods', which did not need an explanation, and sacrifices 'as to the heroes', which needed to be specified because they implied deviation from the norm. Deviations from the norm are observed in sacrifices to the impure Tritopatores (pouring libations of wine 'through the roof, burning the ninth portion of the animal), to the pure Tritopatores (wineless libations), and to Elasteros ('as to the gods', but slaughtering the animal so that its blood flows into the earth).

61) A. Hermary, "Autres cultes dans le sanctuaire", in S. Fourrier - A. Hermary, Amathonte VI. Le sanctuaire d'Aphrodite, des origines au début de l'époque impériale, Paris, 2006, p. 160-164: A dedication to Sarapis, Isis, Aphrodite (or Isis Aphrodite) and their synnaoi theoi for the well-being of Ptolemy VIII, Kleopatra III, and their children, in the sanctuary of Aphrodite in Amathous can now be restored thanks to the discovery of an additional small fragment.

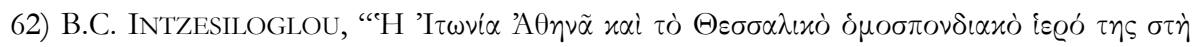

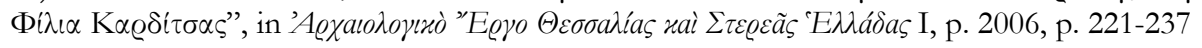
[BE 2007, 351]: Overview of the results of the excavations in a sanctuary at Filia Karditsas (Thessaly), which can be identified as the sanctuary of Athena Itonia. I. discusses the significance of this sanctuary as federal sanctuary of the Thessalians (ff. SEG XXV 653-654; XXXIV 558; LIII 849).

63) B. IPLIKÇIOĞLU, "Bati Pamphylia ve dogû Lykia'da epigrafya araştirmalari 2004”, AST 23.1 (2005) [2006], p. 219-224: In his report on recent epigraphic research in Lykia and Pamphylia, I. mentions several inscriptions from Rhodiapolis. They include dedications of honorific statues to the gods; an honorific inscription for a boy victor in wrestling at the Serapeia Apolloneia; and the end of a honorific inscription for a priestess for life of Meter Theon, who dedicated statues in the goddess' sanctuary. [This inscription is of particular interest because at the beginning it refers to the construction at the expenses of this woman

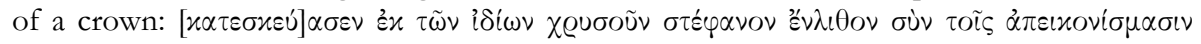
$\tau \tilde{\omega} \nu \sum \varepsilon \beta \alpha \sigma \tau \tilde{\omega} \nu$ ('she had constructed at her own expense a golden crown with inlaid stones 
and with representations of the emperors'); this must have been the crown of the high priestess of the imperial cult.]

64) S. Isager, "The Salmakis Inscription: Some Reactions to the Editio Princeps", in The Salmakis Inscription, p. 9-13: I. summarizes recent publications concerning the date, the author, and the content of this very important metrical inscription from Halikarnassos, which refers to local myths (EBGR 1998, 130; SEG XLVIII 1330).

65) S. Isager, "Halikarnassos and the Ptolemies I: Inscriptions on Public Buildings", in The Salmakis Inscription, p. 133-114: In a study of the relations of Halikarnassos with the Ptolemies, who controlled the city in c. 280-195, I. republishes an inscription which commemorates the dedication of a stoa to Apollon and a King Ptolemy (III?) and a decree which concerns the funding for its construction.

66) M.H. JAMESON, "Troizen and Halikarnassos in the Hellenistic Era", in The Salmakis Inscription, p. 93-107: The metrical inscription from Halikarnassos (supra no. 32) alludes to the foundation of the city by Troizenian settlers $(A \nu \theta \varepsilon \alpha \dot{\delta} \delta \iota)$. J. collects the literary and epigraphic evidence for the relations between the two cities, presenting the relevant texts in an appendix. He adduces inscriptions for the following subjects: the alleged foundation of

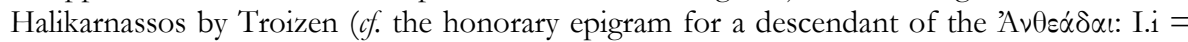
SEG XVI 666; $c$. the list of the priest of Poseidon Isthmios in Halikarnassos: I.h $=$ Syll. ${ }^{3}$

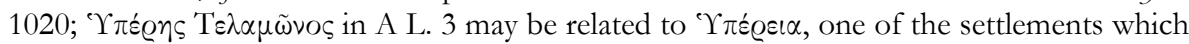
later formed Troizen); the alleged foundation of a temple of Aphrodite by the Halikarnassians in Troizen and the dedication of a statue of Isis (Paus. II, 32, 6; cf. dedications to the Egyptian gods, Arsinoe II, and Aphrodite Akraia Arsinoe: II.b = GIBM 907; II.c = GIBM 908; II.d = SEG VIII 361); the relations of Troizen with Halikarnassos ( $c$. a honorary decree of Troizen for two Troizenians and a man from the Halikarnassos area: III.a = IG IV 750; a honorary decree of Troizen and Halikarnassos for Zenodotos : III.d/e; a honorary epigram of Troizen for Diomedes, a Troizenian or Halikarnassian descendant of 'A $\nu \theta \alpha$ s: III.f $=$ I.Oropos 389); the relations of Theangela with Troizen $(c f$. honorary decrees of Troizen for a man from Theangela and for the city of Theangela: III.b/c).

67) D. KNOEPFLER, "L'inscription de Naryka (Locride) au musée du Louvre : la dernière lettre publique de l'empereur Hadrien ?”, REG 119 (2006), p. 1-34: Ed. pr. of a letter sent by Hadrian to the city of Naryx in Lokris, shortly before his death in 138 CE [already presented in EBGR 2002, 115; SEG LI 641]. In this letter Hadrian confirms the status of Naryx as a polis. In addition to providing a nice definition of what constitutes a polis (participation in the Amphictyony, the Boiotian Koinon and the Panhellenion, existence of a council, magistrates, priests, Greek phylai, Opountian laws, payment of taxes together with the Achaians), the emperor refers to the Roman and Greek poets, who had mentioned Naryx and its heroes (i.e. the Lokrian Aias). In this article, the first part of a detailed study of this document, K. offers an exhaustive commentary of Naryx's participation in the Delphic Amphictyony, the Boiotian League, and the Panhellenion. As regards the enigmatic phrase

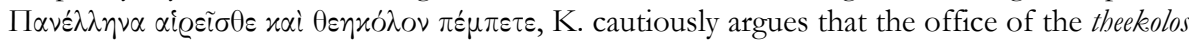
was not an old Lokrian office, but a representative of the Narykeans in the board of sacred officials of the Panhellenion, modelled after the theekoloi in the cult of Zeus in Olympia.

68) R. Koch PietTre, "La Chronique de Lindos, ou comment accommoder les restes pour écrire l'Histoire", in P. BORGEAUD - Y. VOLOKHINE (eds.), Les objets de la mémoire. Pour une approche comparatiste des reliques et de leur culte, Bern, 2005, p. 95-145: K.P. discusses the content of the Lindian anagraphe as evidence for the significance of relics and epiphanies in ancient 
Greece and gives an overview of the motives for the dedications made to Athena Lindia and the origin of the dedicants.

69) A. KolDe, "Paroles de Cobra (Bernand, Inscr. métr. 102)", in Mélanges Hurst, p. 143-154: $\mathrm{K}$. discusses an interesting funerary epigram for a cobra, killed by a man (Inscr. métriques 102; Egypt, Imperial period). The epigram is composed after the model of 'prayers for justice' for the victims of murder; the cobra promises that her offspring, more numerous than the grains of the sand, will pursue this man and his descendants; the murderer will reach Hades

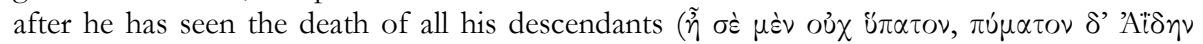

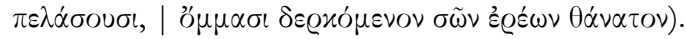

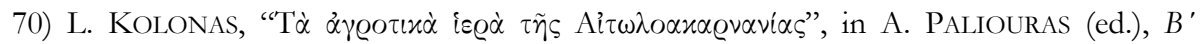

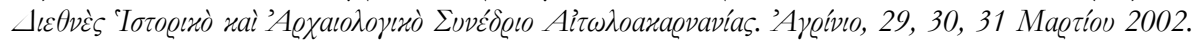
Пழaxtixá, Agrinio, 2004, I, p. 267-292: Ed. pr. of a dedication to (Artemis) Epikrateia found in a rural sanctuary of Artemis at Drymonas Archontochoriou (near ancient Alyzia, Akarnania, 3rd cent.). This epithet, attested for the first time, is mentioned in several dedicatory inscriptions from the same sanctuary. Artemis' sanctuary flourished in the Hellenistic period.

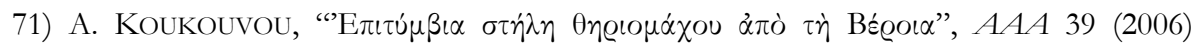
[2007], p. 161-174: Ed. pr. of an interesting grave epigram for a venator (Beroia, late 2nd cent. CE). The relief depicts the venator with a dog fighting against a bear. The epigram reports that Tillorhobos, a native of Beroia, died in his fatherland after fighting against horrible species of wild animals in many cities and after saturating the insatiable Tyche with blood.

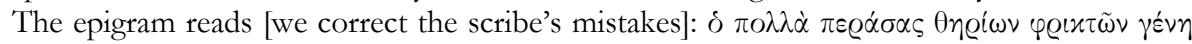

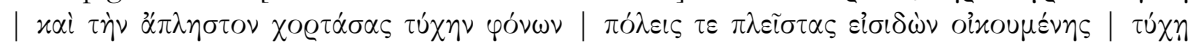

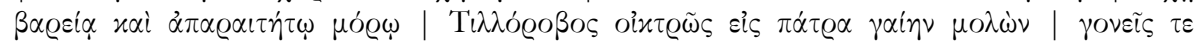

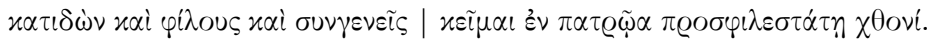

72) V. KRApiVINA - P. Diatroptov, “An Inscription of Mithridates VI Eupator's Governor from Olbia”, ACSS 11 (2005.3/4), p. 167-180: Ed. pr. of an inscription from Olbia $(78 / 77$ BCE), which records the dedication of the curtain of the city wall by Mithridates' VI governor to Meter Theon. Meter Theon in a corona militaris appears on coins issued under Mithridates VI in Olbia; her cult was widespread in the North Pontic region. The second-century city wall of Olbia was dedicated to Plouton, Demeter, Kore, and Demos (N.O. LeIPuns'KA, “Novyi napis z Ol'vii”, Arkheologiya (Kiev) 3 [1990], p. 117-122).

73) C. LeHMler - M. WÖrRle, "Neue Inschriften aus Aizanoi IV: Aizanitica Minora", Chiron 36 (2006), p. 45-111: Ed. pr. of new inscriptions from Aizanoi (all from the Imperial period). Dedications: The most interesting monument is an altar dedicated by a village (Daokometai) to Zeus in fulfilment of a vow ( $x \alpha \tau^{\prime} \varepsilon \dot{u} \chi \eta \dot{\eta} v$; 135). The text reports: 'On 19 Loos, Menophilos was taken by dreadful fear, and (the cult of) Great Zeus of Menophilos

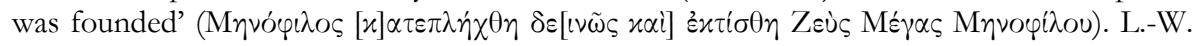
assume that Menophilos' dread was caused by an epiphany and a vision, in which Menophilos experienced 'his' Great Zeus. [One cannot exclude the possibility of divine punishment. In the narrative of the miracle of Zeus at Panamara (I.Stratonikeia 10), when Zeus' fire burned the weapons of the enemy and a sudden storm terrified the assailants, 'many were those who deserted, asking for forgiveness and crying out with loud voice

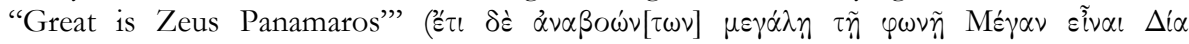
$\Pi \alpha \nu \alpha \dot{\mu} \alpha \varrho \circ \nu)$. In addition to providing a further parallel for the name of a god followed by the name of the cult founder in the genitive (see infra and nos. 79 and 88), this text is a nice example of a spontaneous acclamation ('Zeus is great'), which follows upon a personal 
experience with divine power; the acclamation becomes the epithet of the god, whose cult is founded as a result of this personal experience; in this case, the cult ultimately became a public cult. On such acclamations see A. CHANIOTIS, "Acclamations as a Form of Religious Communication", in H. CANCIK - J. RÜPKE (eds.), Die Religion des Imperium Romanum. Koine und Konfrontationen, Tübingen, 2009, p. 199-218]. A sacrificial table was dedicated by a group of hieroi to Zeus Olympios Kersoullos (137); the centre for the cult of Zeus Kersoullos was in the territory of Hadrianoi (I.Hadrianoi 1-8), from where it was introduced to Aizanoi; the epithet Olympios was hitherto unattested for Zeus Kersoullos. As an epigram reports, a dedication to Kore was made upon the goddess' command, which had been given in a dream: 'we have made this altar for the golden Kore, as she commanded in nightly dreams. And you, blessed one, be propitious and protect the house; and Hekate may assist you' ( $\tau \tilde{\alpha}$

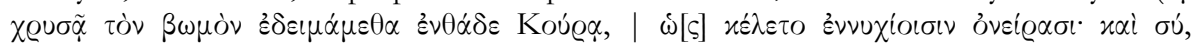

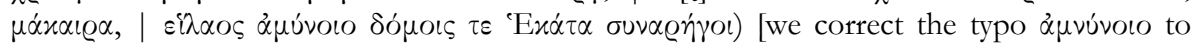

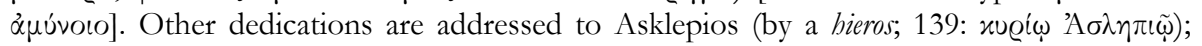
Hosion kai Dikaion (134; cf. 133), Meter Theon (130); Meter Thea Epiktetos (131, an altar:

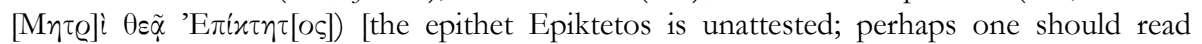

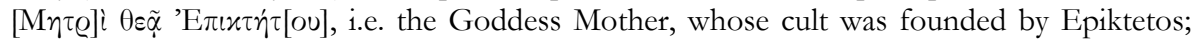
for such theonyms see supra (Zeus of Menophilos), infra nos. 79 and 88, and EBGR 2000, 108 and 2003, 31; 2003, 177; 2005, 45-46]; Meter Es[--] (132); Zeus [--]eteos (136), Zeus Sabazios (138). As regards the bieroi (137 and 139), L.-W. plausibly point out that in these inscriptions this term does not designate subordinate personnel of sanctuaries; it expresses personal devotion to a god. A dedication to an anonymous deity was made on the basis of a

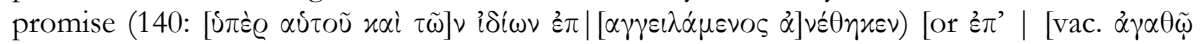

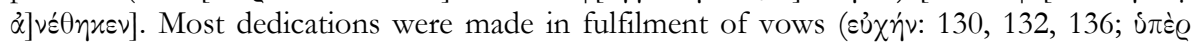

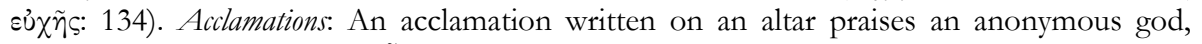

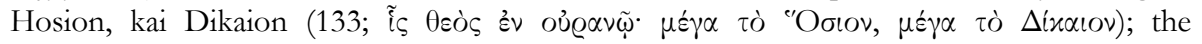
combination of 'the one god' and Hosion kai Dikaion was already attested (e.g. TAM V.1.146), and M. Ricl suspected that the 'one god' may be Helios. K.-W. observe that in the

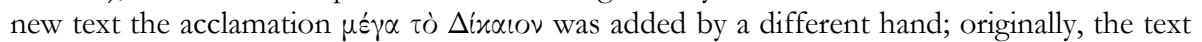

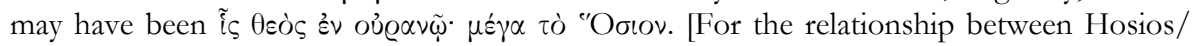
Hosion and Hosion kai Dikaion and the 'one god' one should take into consideration the entire material and the specific features of religious acclamations ( $c f$. supra); my impression is that the pair Hosion kai Dikaion was regarded as a subordinate divinity.] Funerary cult: A funerary altar was dedicated to Apollon and the deceased person (77, Imperial period); altars dedicated to gods and deceased persons are almost exclusively attested in Dorylaion and Nakoleia; they are usually dedicated to Zeus Bronton. An epitaph uses the funerary

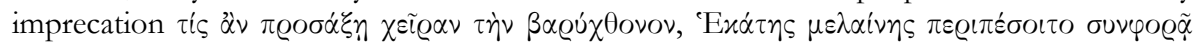

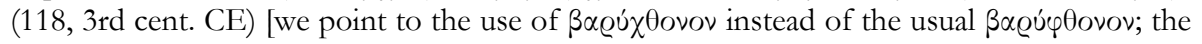
translation 'frevlerische Hand' is not accurate]. A deceased person is designated as a heros (125). Piety: In an epitaph the deceased person has the attribute $\theta \varepsilon 0 \sigma \varepsilon \beta \eta \dot{~}$ (128) [not necessarily related to the group of the theosebeis, for which see EBGR 1998, 190].

74) É. LHÔTE, Les lamelles oraculaires de Dodone, Geneva, 2006 [BE 2007, 339]: We will return to this important publication in more detail in the next issue of EBGR. Here, we briefly summarize its content. L. presents critical editions of 167 oracular enquires from Dodona (only already known texts), with ample linguistic commentary. This material, especially the enquires of private individuals (nos. 18-153), is a very important source of information for religious mentalities.

75) C.C. LORBER - O.D. HoOver, "An Unpublished Tetradrachm Issued by the Artists of Dionysos", NC 163 (2003), p. 59-68 [SEG LV 1973]: L.-H. publish a unique coin (a 
wreathed tetradrachm) issued by the Ionian and Hellespontine branch of the Dionysiac

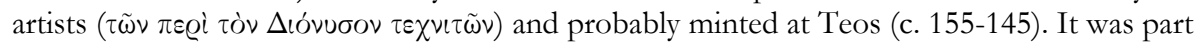
of a one-time emission, possibly to commemorate an important event (perhaps the foundation of the 'A $\tau \tau \alpha \lambda \iota \sigma \tau \alpha$ i by the leader of the association, the flutist Kraton). The coins of this emission may have been given to foreign guests or as prizes to participants in competitions. In connection with this important find, the authors review the epigraphic evidence for the various branches of the associations of Dionysiac artists and especially for the Tean branch under the leadership of Kraton and its links to the Pergamene court.

76) B. MACLACHLAN, “Kollyra's Curse”, MEP 9/10 (2004/05), p. 249-256: M. republishes a prayer for justice from Lokroi Epizephyrioi (3rd cent.; IG XIV 644) and compares it with similar curses written by victims of injustice - in this case the victim of theft ( $c$. I.Knidos 147148; SEG XXXVIII 1568) - and with confession inscriptions [cf. EBGR 2004, 44]. We

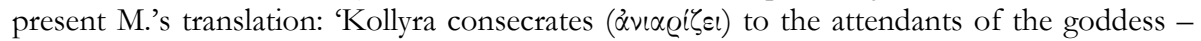
her cloak, the dark-coloured one, that someone took and is not giving back, and - uses it and knows where it is. Let this person dedicate to the goddess ( $\alpha \nu \theta \varepsilon i \eta \eta \tilde{\alpha} \iota \theta \varepsilon \tilde{\omega} \iota)$ twelve times

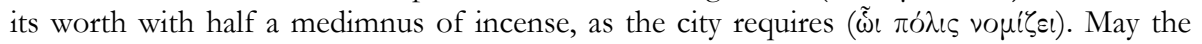

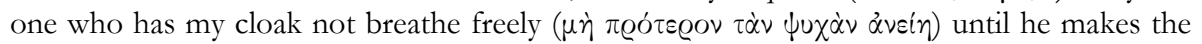

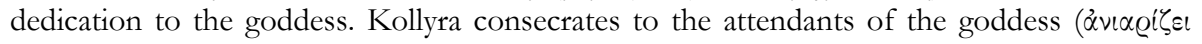

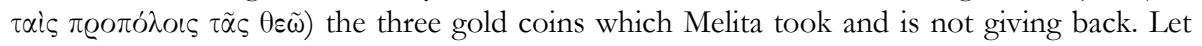
her dedicate to the goddess twelve times their worth with a medimnus of incense as the city requires. May she not breathe freely until she has made the dedication to the goddess. If she should drink with me or eat with me and I do not know it, or go under the same roof as I,

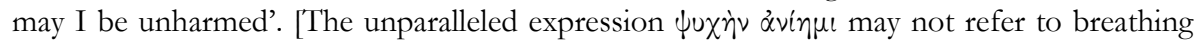
( $c f . \pi \nu \varepsilon \tilde{u} \mu \alpha \dot{\alpha} \nu i \eta \mu \iota)$ but to the burden on the thief's soul and conscience.] The reference to the sacred personnel (of the sanctuary of Persephone?), which shows the public nature of this curse, finds a parallel in a judicial prayer from Delos (A. HAUVETTE-BESNAULT, "Fouilles de

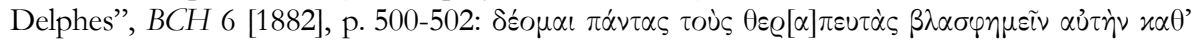

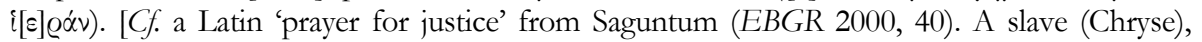
who was the victim of theft by another slave, invoked Iao and donated to him the stolen money, expecting the god to punish the thief. The defigens also promised a reward to a cult functionary for his services (do pecuniam onori sacricola). A reward for the cult personnel makes sense only if the cult personnel were involved in the ritualised cession of the stolen property perhaps also in the cursing; on this subject see A. CHANIOTIS, "Ritual Performances of Divine Justice: The Epigraphy of Confession, Atonement, and Exaltation in Roman Asia Minor", in H.M. COTTON et al. (eds.), From Hellenism to Islam: Cultural and Linguistic Change in the Roman Near East, Cambridge, 2009, p. 115-153]. M. notes the literary qualities of Kollyra's text, its visibility, and the expectation that the goddess' attendants will be executors of the divine power [or involved in a curse ceremony].

77) V. Malamidou, Roman Pottery in Context. Fine and Coarse Wares from Five Sites in NorthEastern Greece, Oxford, 2005 [BE 2006, 94]: M. presents stamped vases found at the sanctuary of Heros Auloneites at Kepia in Macedonia (p. 61f.; Imperial period; ff. EBGR 1992, 117). The

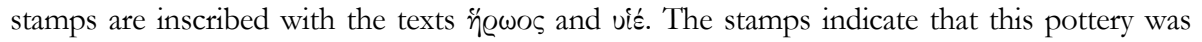
locally produced for the sanctuary [cf. ead., "For Middle Roman Ceramic Groups from Eastern Macedonia", in M.B. BRIESE - L.E. VAAG (eds.), Trade Relations in the Eastern Mediterranean from the Late Hellenistic Period to Late Antiquity. The Ceramic Evidence, Odense, 2005, p. 106].

78) H. Malay, “A New Dedication from the Katakekaumene”, EA 39 (2006), p. 84-85: Ed. pr. of a fragmentary and puzzling text from Maionia (Imperial period), which M. plausibly

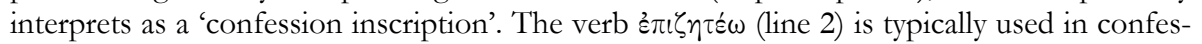


sion inscriptions in connection with divine punishment. A woman explains (according to M.'s translation): 'therefore, deceived by Menas, I set up (this stele) for the distressed (or:

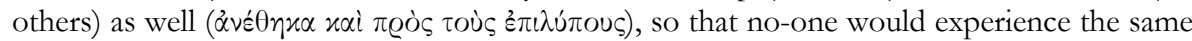
sufferings. He (Menas) wanted to - - to my body (or: slave); for this reason, I read out... (invoked) and asked (the goddess) and performed to the outmost of my ability the things

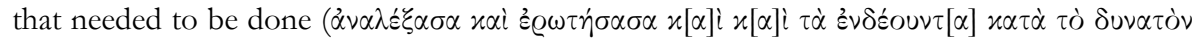
$\pi \circ \eta \dot{ } \sigma \alpha \sigma \alpha)$, so that also the distressed ones (or: others) would receive (divine) favour (' $\chi^{\prime} \chi 0 v \sigma \iota \nu$

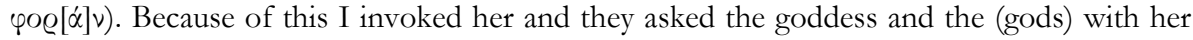

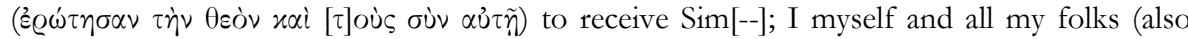

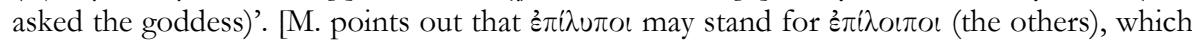
I find more probable. Instead of $\alpha \nu \alpha \lambda \hat{\varepsilon} \xi \alpha \sigma \alpha$ ('read out', 'invoke'?, or 'select'?), perhaps we should read [----] $\alpha \nu \alpha \lambda \varepsilon^{\prime} \xi \alpha \sigma \alpha$ (the reading of the first letters is not certain). The expression

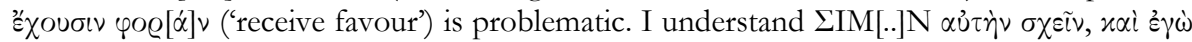

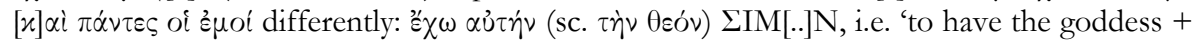
attribute (e.g. propitious), both I and all my people'; for this construction $c f$. the formulas

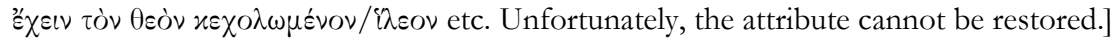

79) H. MALAY, “Some Inscriptions from Lydia up for Auction”, EA 39 (2006), p. 87-97: M. identifies Lydia as the provenance of a group of stelae offered for sale by Edgar Lowen. He reads the texts from the photos. This material includes dedications to Thea Andene (1, 278 CE), whose cult is attested for the first time, and to Meter Motyllene (2), whose cult epithet (attested here for the first time) derives from Motula ( $c$. Mes Motyllites). The epitaphs include two for priests (10 and 15). One of them is of particular interest (10, $93 \mathrm{CE})$. It

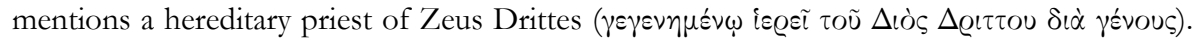
M. points out that Zeus Driktes is already attested. [Unfortunately, because of the genitive

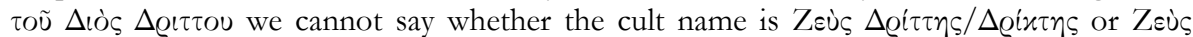
$\Delta \varrho \iota \tau \tau o v / \Delta \varrho \iota x \tau o v$, i.e. a cult of Zeus founded by Drittes/Driktes; on this phenomenon see supra no. 73.]

80) H. MALAY, “Three Dedications to Zeus Keraunios”, EA 39 (2006), p. 103-104: Ed. pr. of three dedications to Zeus Keraunios, from Lydia (1), Maionia (2), and the Kaystros Valley (3), all of them from the Imperial period. Two of them were made in fulfilment of vows (23: $\varepsilon \dot{\chi} \chi \eta^{\prime} \nu$ ). The third dedication was made by a man for the rescue of his daughter (3: [i் $\left.\pi \dot{\varepsilon}\right]$

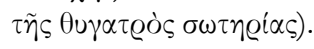

81) H. MALAY - M. RiCL, "Some Funerary Inscriptions from Lydia", EA 39 (2006), p. 4982: Ed. pr. of an epitaph from north-east Lydia with a funerary imprecation (36, $122 \mathrm{CE}$ ): 'if

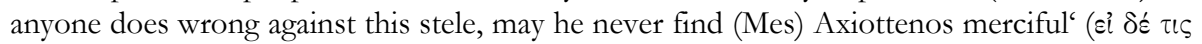

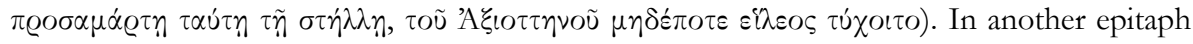
from Kole (44, Imperial period) the deceased person is called $\ddot{\eta} \varrho \omega \varsigma$.

82) F. Maltomini, "Una lamella d'oro del Museo Archeologico Nazionale di Cividale del Friuli”, ZPE 156 (2006), p. 103-108 [BE 2007, 48]: Ed. pr. of a gold lamella contained in a gold capsule found near Pozzuolo (Udine, 4th cent. CE). The lamella is inscribed with a phylactery. The text begins with an invocation of Arsamon (Horos, the son of Amon),

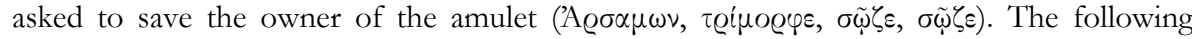
words ( $\pi \alpha \varrho \theta \varepsilon ́ v \alpha l, \alpha \mu u ́ v \tau \alpha, \pi \varrho \omega \tau o \mu \alpha \dot{\alpha} \chi \varepsilon)$ are interpreted by M. as attributes of Arsamon ('vergine, difensore, combattente in prima linea'). The rest of the text consists of magical words and names, including very common formulae such as $\alpha \beta \lambda \alpha \nu \alpha \theta \alpha \nu \alpha \lambda \beta \alpha \alpha x \varrho \alpha \mu \alpha \chi \alpha \mu \alpha \varrho$,

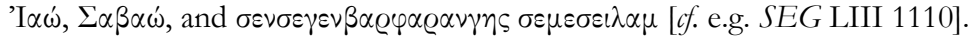


83) C. MAREK, Die Inschriften von Kaunos, Munich, 2006: We only mention here the publication of this important corpus, which will be presented in detail in the next issue of EBGR.

84) A. MARTínez FernándeZ - N. TSATSAKi - N. Kapranos, "Una inscripción inédita de Chamalevri”, ZPE 157 (2006), p. 87-94 [BE 2007, 27]: Ed. pr. of a building inscription from Chamalevri, east of Rethymnon on Crete (2nd cent. BCE). It records the restoration of a

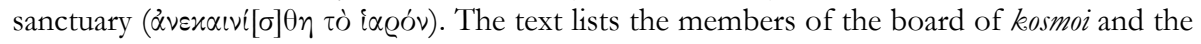
man who proposed the decree.

85) L. MigeotTe, "La haute administration des finances publiques et sacrées dans les cités grecques", Chiron 36 (2006), p. 379-394 [BE 2007, 168]: Surveying the epigraphic material from Boiotia, Miletos, Pergamon, Priene, Magnesia on the Maeander, Thasos, Arkesine, Ephesos, Samos, Smyrna, and other cities, M. demonstrates that the Greek cities undertook efforts to establish a coherent and efficient administration of public and sacred funds (iع $\grave{\alpha}$

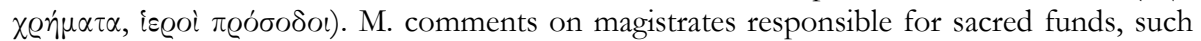

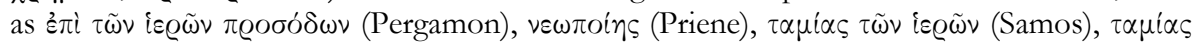

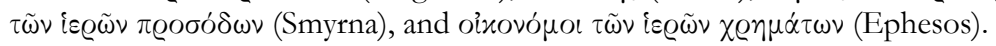

86) N.P. MILNER, “Ancient Inscriptions and Monuments from the Territory of Oinoanda", AS 54 (2004), p. 47-78 [SEG LIV 1417, 1424; BE 2006, 385]: M. republishes a funerary

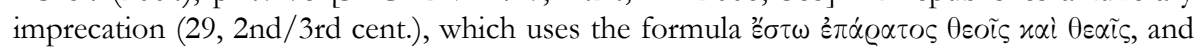
the epitaph of a former high priest of the imperial cult, who is designated as $\ddot{\eta} \varrho \omega \varsigma$ (1, IGR III 1506, 2nd cent. CE).

87) A. Nichols - R. Wagman, "Three Perirrhanteria from the Epidaurian Asclepieum", ZPE 155 (2006), p. 137-138: Ed. pr. of three inscribed perirrhanteria from the sanctuary of Asklepios in Epidauros. One of them was dedicated by a woman (1, undated). A second was dedicated by a Euarchidas to Athena (2); this man dedicated also a perirrhanterion in the sanctuary of Apollon Maleatas ( $I G I^{2}$ 174). The third inscription is very fragmentary.

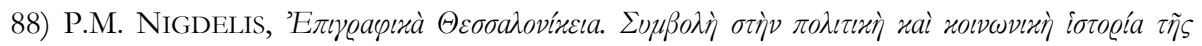

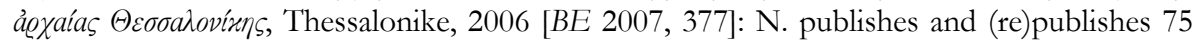
inscriptions of Thessalonike with thorough commentaries. New texts are marked with an asterisk. Cult associations: A large part of the book is dedicated to associations. N. republishes an important list of the members of a $\sigma \pi \varepsilon i \varrho \alpha$, a Dionysiac association (p. 101-128; SEG XLIX 814; EBGR 1999, 144; c. 200-250 CE), with several new readings and restorations of

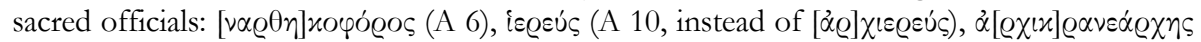
(A 17), $\mu \alpha[\gamma \alpha \varrho \varepsilon u ́ s]$ (A 18). N. comments inter alia on the size of the association (at least 30 members), the existence of at least four $\alpha \varrho \chi \mu \nu$ ó $\alpha$, which may be an indication that the

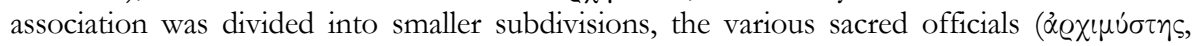

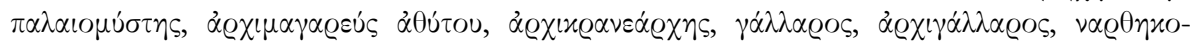

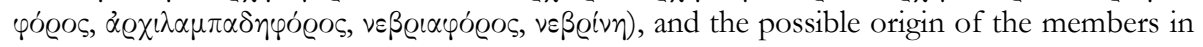
Asia Minor. N. follows P. Boyancé in interpreting the title $\mu \eta_{i} \eta \eta \varrho ~ \sigma \pi \varepsilon i \varrho \alpha \varsigma$ as an indication that the myth of Semele was represented during the rituals. [More probably, it is an

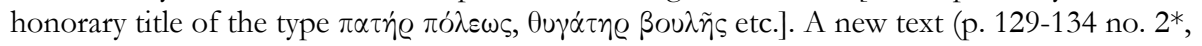
$218 \mathrm{CE}$ ) attests for the first time an association of worshippers of Dionysos Mousaiou Horophoros (Mousaios being the founder of the cult). It is a dedication of an altar and a magaron made by an $\alpha \varrho \chi \mu \alpha \iota v \alpha \dot{s}$ and a $\mu \alpha \gamma \alpha \varrho \varepsilon u ́ \varsigma$. Dionysos Horophoros was probably

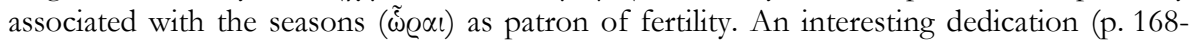
177 no. 8*, 1st/2nd cent.) provides information concerning the banquets organised by the

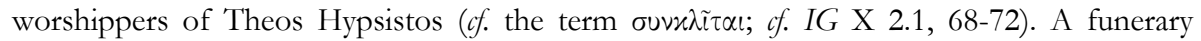
inscription (p. 135-146 no. $3=I G \times 2.1,480,2$ nd/3rd cent.) is reconstructed as an epitaph 


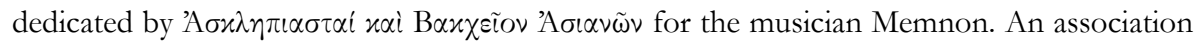

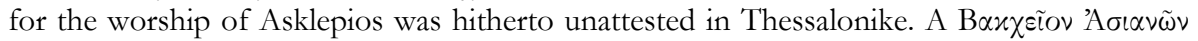

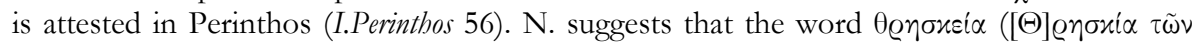

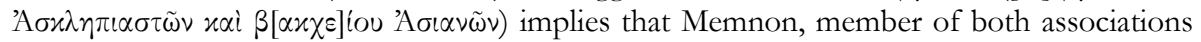
was recipient of a funerary cult. [An alternative interpretation is that the term $\theta$ enoxsi $\alpha$ does not have its usual meaning (worship and piety; see now EBGR 2004, 85), but is used as a

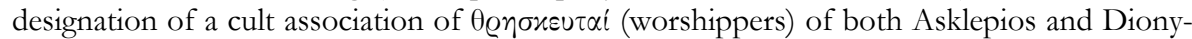
sos.] Another epitaph (p. 147-151 no. 4*) was set up by a hitherto unattested association ( $\left.\sigma u \vee \eta^{\prime} \theta \varepsilon ı \varsigma\right)$ for the worship of 'Artemis Gourasia, whose sanctuary is near Acherdos (the

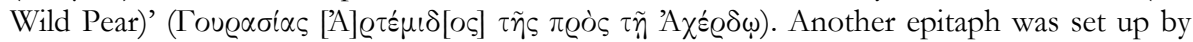

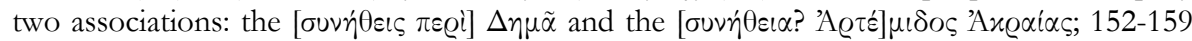

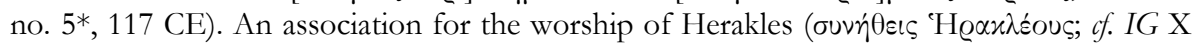
2.1, 288-289 and SEG XLIII 462) honoured its deceased priest (160-162 no. 6*, 2nd cent. CE). Another epitaph (of a perfume merchant) was set up by the association of worshippers

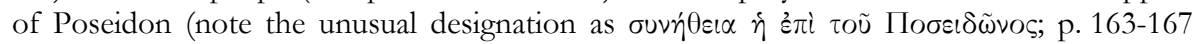
no. $7^{*}$, ca. 150-200). The secretary of the association donated a jug ( $\left.x \alpha \tau \dot{\alpha} \chi \nu \sigma \iota \varsigma\right)$ and a handle $\left(\chi \varepsilon £ \circ \lambda \alpha \beta \eta^{\prime}\right)$. The fragmentary statute of an association concerns the burial of its members; the identity of this association cannot be determined, but, as one can infer from the expression $x \alpha \tau \dot{\alpha} \tau \dot{\alpha} \varsigma \delta o \chi \alpha \dot{\alpha}$, it organised banquets (196-201 no. 13*, early 3rd cent. CE). Other associations, which dedicated epitaphs for their members, include a cult association for

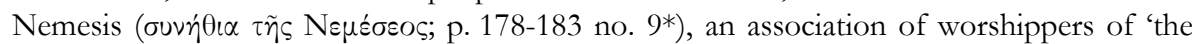
hero Aineias', i.e. the founder of Aineia (206-211 no. 15, $125 \mathrm{CE}$ ), professional associations (mule-drivers: 184-188 no. 10*; makers of garlands: p. 188-191 no. 11*), and a unique association of $\varphi$ i $\lambda$ о $\alpha$ ix $\tau о \varrho \varepsilon \varsigma$, 'lovers of jokes' or 'lovers of entertainment/entertainers' (191196 no. 12*) [cf. EBGR 1999, 20, on an association dedicated to recreational celebrations]. These inscriptions provide information concerning the officials of the cult associations:

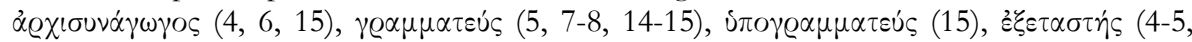

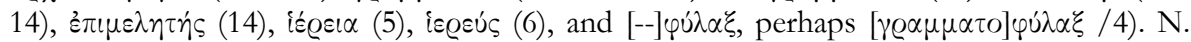
also restores a fragmentary honorary inscription of an association of worshippers of the Egyptian gods (211-216 no. $16=I G \times 2.1,16)$. Cult officials: We note the epitaph of a sacerdos (p. 325-327 no. 16*). Ruler cult. An inscribed base of a statue of Alexander the Great dedicated by the city; Alexander is designated as the son of Zeus ( $\beta \alpha \sigma i \lambda \varepsilon \dot{\varepsilon} \alpha \mu^{\varepsilon} \gamma \alpha \nu \Delta$ เò

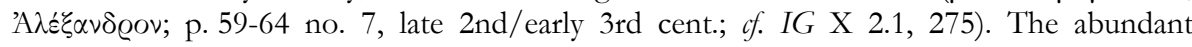
evidence for the Imperial cult includes a dedication to Livia (p. 35-40 no. 1*); a dedication by a high priest of the Sebastoi and agonothetes for the well-being of Septimius Severus

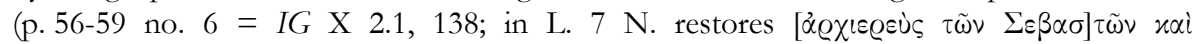

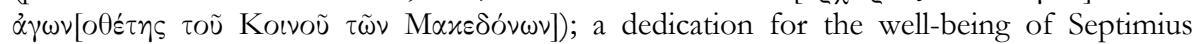
Severus (p. 70-72 no. $9 *$ ); three invitations to munera by the high priest of the provincial imperial cult (p. 73-93 no. 10 = EBGR 2000, 205; SEG XLV 816-817, 252-260 CE). Festivals: As regards the festival, in which the sponsor of no. 10 served as agonothetes in 259

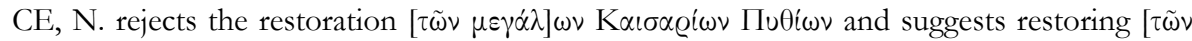

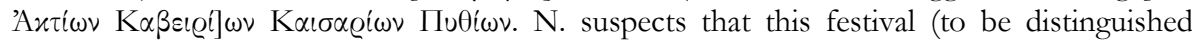
from the Kaisareia Epinikia Kabeiria Pythia, celebrated in 260 CE), was introduced in 255 CE, after the successful repulsion of the Goths. The volume includes several epitaphs of gladiators (231-248 nos. 3-6*). Funerary cult: In addition to the inscriptions, which concern the burial of members of associations (see supra), there are epitaphs in which the deceased person is called $\ddot{\eta} \varrho \omega s$ (p. 253-257 no. 8*). As regards the terminology of funerary monuments, we single out the terms $\tau \varrho \iota v \chi o ́ \varsigma=\theta \varrho \iota \gamma x o ́ \varsigma$ (enclosure of a burial ground; p. 363366 no. $\left.3^{*}\right)$. A very interesting monument is a fragmentary sarcophagus of unknown provenance (p. $405-408$ no. 15 , early 3rd cent. CE) [a pierre errante from Asia Minor?]. The 


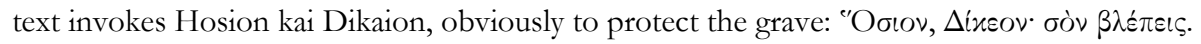

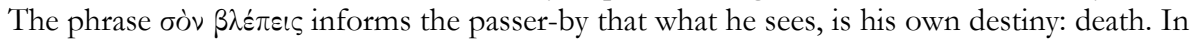
an Appendix (p. 411-491) N. presents the text of 60 inscriptions from other places, concerning either Thessalonike or individuals from this city (all of them known texts, which we do not include in this presentation).

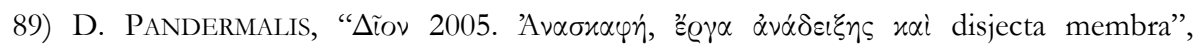
AEMTh 19 (2005) [2007], p. 373-379 [SEG LV 679]: P. reports the discovery of the lower part of a marble statue of Zeus with an inscribed base (Dion, $211 \mathrm{CE}$; p. 375). The statue was dedicated by the priest C. Postumius. This priest was already known from an inscription in the sanctuary of Zeus Hypsistos. He also mentions a marble relief plaque with the representation of a rider and a snake (p. 376, late Classical period); it was set as an epitaph for a heroized man.

90) D. Pandermalis, "Sĩov 2006", AEMTh 20 (2006) [2008], p. 567-575: D. presents a dedication to Asklepios Soter found re-used in a bath (Dion, Imperial period; p. 574) [on

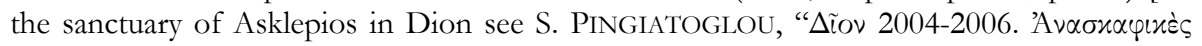

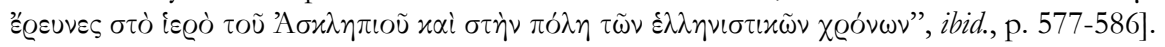

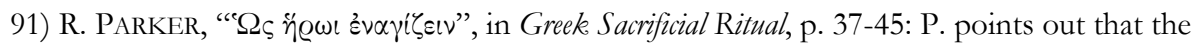
ancient sources do not make a distinction between 'Olympian' and 'chthonic' sacrifice, distinguishing instead between sacrifices to gods $(\theta \dot{\omega} \omega)$ and sacrifices to heroes ( $\varepsilon^{2} v \alpha \gamma i \zeta \omega ; c f$. the cult regulation of Selinous concerning purification: SEG XLIII 630). The Attic sacrificial calendars (LSCG Suppl. 19; LSCG 18; IG I 256 bis) show that sacrifices to heroes were occasionally followed by feasts. Although generalizations should be avoided, common features of heroic sacrifice include the burning of more meat than in normal sacrifice, the slaughtering of victims into the ground, the consumption of the meat on the spot (prohibition of $\dot{\alpha} \pi \circ \varphi \circ \varrho \alpha$ ), and the pouring of blood into pits.

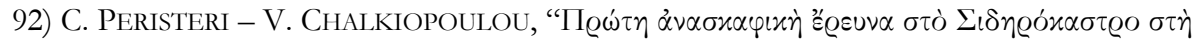

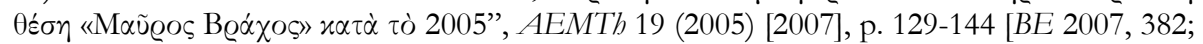
SEG LV 688]. Ed. pr. of a dedication to Apollon found in the area of a rural sanctuary of Apollon at the site Mavros Vrachos near Siderokastron Serron in Macedonia (area of Herakleai Sintike; p. 131, 4th cent.).

93) M.F. Petraccia, "Donne e culti nelle province romane dell'impero. Il caso della Macedonia", in Donna e vita, p. 431-438: Collection of attestations of priestesses and high priestesses of the imperial cult in Roman Macedonia (Beroia, Thessalonike, Styberra, Stobi, Kissa, Philippi) and discussion of their title, family relations, and economic background. She

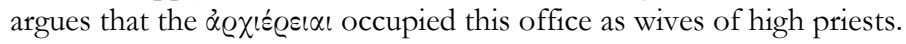

94) M.-Z. Petropoulou, “A Seleucid Settlement on Falaika”, EA 39 (2006), p. 139-147: An important inscription from Ikaros/Falaika in the Persian Gulf containing a letter of a Seleucid king concerning the sanctuary of Soteira, its asylia, and the establishment of a musical and athletic contest (SEG XX 411; most recent edition in I.Estremo Oriente 421-422). Different dates have been suggested for this text, which is of great significance for the religious policy of the Seleucid, ranging from 241 to 166 BCE. After examining a squeeze, P. restores the date as the 74th year of the Seleucid era (238/7 BCE) and identifies the king as Seleukos II. She also suggests that the king's aim was not to re-people a depopulated settlement, but to unite small settlements into one.

95) G. PETZL - E. Schwertheim, Hadrian und die dionysischen Künstler. Drei in Alexandria Troas neugefundene Briefe des Kaisers an die Künstler-Vereinigung, Bonn, 2006: This is certainly the most important inscription published this year (only three years after its discovery!). It is a 
dossier of three letters (90 lines) sent by Hadrian to the Dionysiac artists with his instructions concerning the organisation of contests - inter alia, the duties of agonothetai and other authorities, money prizes for winners of contests, membership in the association of artists, and more importantly the establishment of a cycle of contests in a strict sequence (Stratonikeia, $134 \mathrm{CE}$ ). We will present this text in detail in the next issue of the EBGR, incorporating remarks made by other scholars after its first edition.

96) O. PICARD, "Les $\chi \varrho \eta ́ \mu \alpha \tau \alpha$ d'Apollon et les débuts de la monnaie à Delphes", Topoi 12/13 (2005), p. 55-68 [BE 2006, 220; SEG LV 566]: P. examines some aspects of monetary practices in early Delphi. He argues that Delphi originally had an inventory of dedications (cf. Herod., I, 50-51; Diod., XVI, 27, 4), albeit not an inscribed one (p. 56-58). One should distinguish between dedications to Apollo, which were property of the god for ever, and temporary deposits $(\pi \propto \varrho \alpha x \alpha \tau \alpha \theta \tilde{\eta} x \alpha \iota)$ attested in CID IV 2 (cf. Plut., Lysandros, 18, 3). This fragmentary inscription does not concern banking activities, but gold and silver objects (including money) brought to the sanctuary for safety and deposited there (p. 58-61). Evidence for the early use of money for the payment of fines and contributions to the cult is provided by various inscriptions (late 6th-late 4th cent.): CID I 1-3, 8-9bis; BE 1970, 312 (p. 61-65). Already as early as the late 6th cent. the Amphiktyony estimated the expenses for the construction of the temple using the Aeginetan standard (Herod. II, 180; p. 65-67).

97) F. QUANTIN, "Le dieu Pan au féminin à Bouthrôtos: une influence italienne", in É. Deniaux (ed.), Le canal d'Otrante et la méditerrane antique et médiévale. Colloque organisé à l'Universit de Paris X - Nanterre (20-21 novembre 2000), Bari, 2005, p. 67-79: Q. republishes two dedications set up by the same man (Kasianos) for Pan Teletarches and Pasa in Bouthrotos (2nd/1st cent.) [EBGR 1988, 26]. Q. points out that there is evidence for an association of Pan with mystery cults and collects evidence for the connection of Pan with Dionysos. By contrast, although Pan was associated with goddesses (the Nymphs, Megale Meter, Meter Theon) in Greece, the existence of a female consort (Pasa) is only attested in South Italy and possibly in the Mycenaean Linear B texts (Pasaja). A detailed study of the literary and iconographical evidence for divine dyads in Italy (Faunus and Fauna, Silvanus and Silvana, Liber and Libera) suggests that Kasianos' dedication was the result of cultural influence from Italy.

98) N. RadeVA Girod, "Les mystères d'Andania. Traduction de l'inscription no. 65 de Lois Sacrées des cités grecques, Sokolowski (1969)", in Mélanges Hurst, p. 357-365: R.G. translates the text of the sacred regulation of the mysteries of Andania [see now supra no. 36].

99) A. RetZlefF - A. Majeed Mjely, "Seat Inscriptions in the Odeum at Gerasa (Jerash)", BASOR 336 (2004), p. 37-47 [SEG LIV 1691]: Publication of 30 inscriptions recording seat reservations in the north theatre of Gerasa [cf. already EBGR 2006, 3]. Most of them mention the names of tribes. The twelve tribes were named after deities (Aphrodite, Apollon, Artemis, Asklepios, Athena, Demeter, Hadrian, Hera, Herakles, Leto, Poseidon, Zeus).

100) N. RoBERTSON, 'Sacrifice to the Sea: a Custom prior to the 'Olympian' and 'Chthonian' Categories?”, in Greek Sacrificial Ritual, p. 85-96: R. collects the evidence for a particular type of sacrifice, the plunging of animals into the sea. This custom is epigraphically attested in

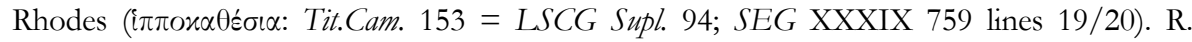
argues that it is a magic ritual of very early origin, which was gradually assimilated into normal animal sacrifice.

101) D. Rousset, "Les inscriptions de Kallipolis d'Étolie", BCH 130 (2006), p. 381-434: Ed. pr. (p. 421 no. 20) of a very interesting dedication from Kallipolis (4th/3rd cent.): Nixì

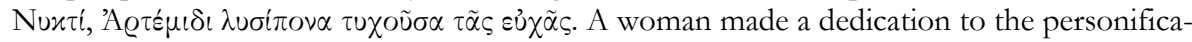


tion of the Nights and to Artemis in fulfilment of a vow; the dedication is designated as 'offering of deliverance from pain' ( $\left.\lambda \nu \sigma^{i} \pi \circ \nu \alpha\right)$. Dedications to Nyx are very rare.

102) D. Rousset, “Affranchissements de Physkeis en Locride occidentale”, BCH 130 (2006), p. 349-379: Ed. pr. and republication of ten manumission records from the sanctuary of Athena in Physkos (west Lokris, 2nd cent.); the manumissions nos. 1-3 and 10 were already known (IG IX 2.1, 671 and 676a-b), but R. presents improved editions. The texts use various

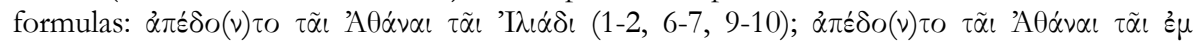

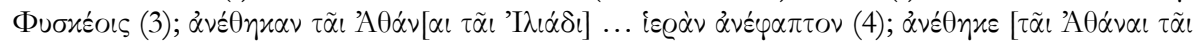
'I $\lambda i \alpha \dot{\delta} \delta$...

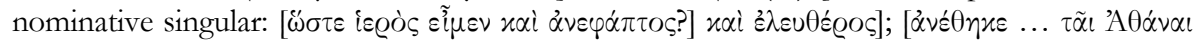

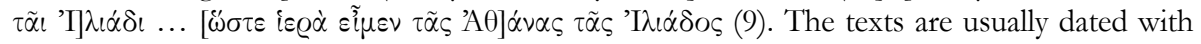
reference to the agonothetes of the Lokrian koinon $(1-5,7,9)$. As regards the calendar, some months are designated with numerals $(1-4,7)$, but there are also references to the months Panamos in Kallipolis (3), Agreios in the Dymanes (5), Hychaios in Physkos (6), and Hermaios (10). R. also publishes an inscription copied by P. Jamot from the area of Malandrino (territory of Physkos or Kallipolis, 11). The fragmentary text is a dedication to a series

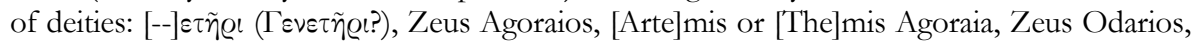

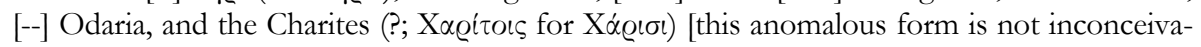

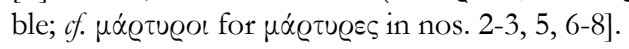

103) I. RUTHERFORD, "Andros at Delphi. CID 1.7 and Insular Theoria”, in J. ChrysosTOmides, C. Dendrinos, J. Harris (eds.), The Greek Islands and the Sea. Proceedings of the First International Colloquium held at The Hellenic Institute, Royal Holloway, University of London, 21-22 September 2001, Surray, 2004, p. 59-75: R. discusses the theoriai sent by Greek islands to Delphi, focusing on the regulations relating to a theoria of Andros (CID I 7; LSCG Suppl. 38; 5th cent.). He reconstructs the procedure of the theoria and discusses possible historical contexts. Evidence for Andrian theoriai is provided by the Delphic accounts, which mention Andrian delegations (CID II 22/23), but also by a paian of Simonides (PMG 35f ed. Page; ca. 510-480), which suggests an early date for this regulation (ca. 500-480). A comparison with the treaty between Skiathos and Delphi concerning a theoria (CID I.13) suggests that the regulation concerning the Andrian theoria was an Andrian sacred law and not a treaty.

104) C. SCHULER, "Inschriften aus dem Territorium von Myra in Lykien: Istlada", Chiron 36 (2006), p. 395-451. C. publishes 23 inscriptions found in an ancient settlement at Istlada (in the territory of Myra). Most texts are inedita. There is only one dedication: the statue of a man was posthumously dedicated to the gods by his father and brother $(1$; late Hellenistic or early Imperial period). All the other texts are epitaphs, usually mentioning fines for the violation of the grave (3rd cent. BCE-2nd cent CE). We note numerous funerary impreca-

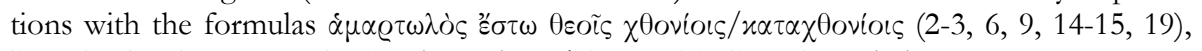

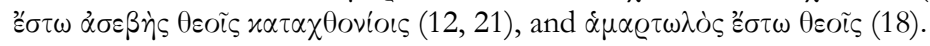

105) H. SiARD, “Un règlement trouvé dans le Réservoir de l'Inopos à Délos”, BCH 130 (2006), p. 329-348: Ed. pr. of a regulation for the protection of a water reservoir (not a river) called Inopos in Delos; the regulation, probably the Hellenistic copy of a regulation of the Classical period, forbids washing, bathing and throwing stones in the river; violators were liable to a fine of five drachmas, payable to the sanctuary of Apollon. In an appendix, S. rejects the assumption that there was a sanctuary or cult of Inopos on Delos.

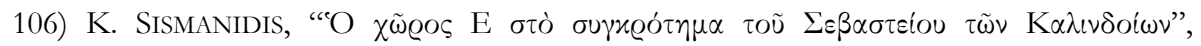
AEMTh 20 (2006) [2008], p. 249-262: Two new epigraphic finds. An inscription found near room E of the Sebasteion reports that the sons of the priest of Zeus, Roma, and Augustus 


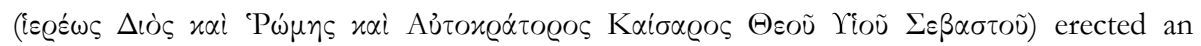
exedra, a bouleuterion, and a porticus in $88 \mathrm{CE}$. The bouleuterion may in fact be room E.

107) C. Sourvinou-Inwood, "Hermaphroditos and Salmakis: The Voice of Halikarnassos", in The Salmakis Inscription, p. 59-84: S. offers an extensive study of the myth of Hermaphroditos and its motifs in the light of the new metrical inscription from Halikarnassos (cf. supra nos. 32, 64-66).

108) J.-Y. STRASSER, "Une inscription de Kéramos, le coureur Politès et la Carie 'Trachée", RE $A 106$ (2004), p. 547-568 [SEG LIV 1082): S. republishes a fragmentary list of athletic victories from Keramos (I.Keramos 15, late 1st cent. CE). According to his restoration, the list records the victories of a runner (Polites of Keramos?; cf. Paus., VI, 13, 3-4) in enoplios, diaulos, and stadion at Syracuse, Apollonia (of Illyria), and Ephesos (Koinos tes Asias).

109) J. TAITA, "Proxenoi 'santuariali' all'oracolo di Zeus ad Olimpia: profilo giuridico e funzioni”, MEP 9/10 (2004/2005), p. 87-114 [SEG LIV 490]: T. studies the meaning and function of the proxenoi known from inscriptions in Olympia. Assuming the existence of an amphictyony in Olympia, which existed until c. $450 \mathrm{BCE}$, T. argues that the term proxenos designates sacred officials, possibly members of a board, sent by the member states of this amphictyony. The proxenoi offered assistance to worshippers but also had judicial authority ( $c f$. the proxenoi of the Delphic amphictyony); e.g. they had the authority to remove from the altar of Zeus violators of treaties (IvOlympia 10) and individuals who had committed sacrilege (IvOlympia 13). The earliest attestation of the proxenoi (along with the sacred officials

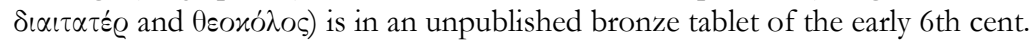

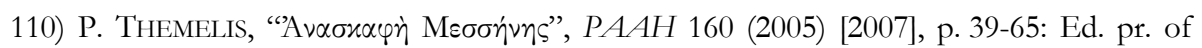
several inscriptions found during the excavation in Messene. An honorary inscription for Hadrian was set up by Tib. Claudius Macer Campanus, the son of Tib. Claudius Saithidas Caelianus, high-priest and Helladarches of the Achaian Koinon for life (p. 43). A dedication found in the theatre was made by the agonothetes of the Dionysia (p. 44, late 3rd cent. BCE).

111) P. Thonemann, "Neilomandros. A Contribution to the History of Greek Personal Names", Chiron 36 (2006), p. 11-43 [BE 2007, 125]: T. collects and discusses personal names

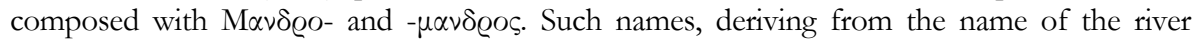
Maiandros (not a god Mandros), are found scattered across the Greek world, but there is a concentration in Ionia (Magnesia on the Maeander, Miletos and its colonies, and Samos). Discussing the existence of double theophoric names (30-33), T. points out that such names are to be found only in Egypt (e.g. Horapollon, Hermanoubis); names such as Athenomandros, Dionysomandros, Dionysermos etc. are not double theophoric names, but composita of the name of a god and the name of a river. [Although T.'s view is supported by strong arguments, the derivation of the overwhelming majority of the mandros-names from the name of the river does not exclude the possibility that in some cases this river was worshipped as a god. Especially the names Mandrodoros, composed according to the common pattern of theophoric names in -doros (e.g. Apollodoros, Dionysodoros, Artemidoros etc.; discussed by T., ibid., p. 14 with reference to EBGR 1998, 65), and Mandronax ( $c f$. Heronax, Helianax, Metronax, Poseidonax, Pythonax etc.), suggest that the bearers of these names attributed to the river divine status; $c$. the remarks of L. DuBOIS, BE 2007, 125; for river-gods in Asia Minor see e.g. EBGR 1996, 107 (Kalykadnos); 2000, 178 (Aneinos), 180 (Meles), 187 (Euros); 2001, 80; 2004, 118].

112) S.R. TOKHTAS'EV, “The Bosporus and Sindike in the Era of Leukon I: New Epigraphic Publications", ACSS 12 (1/2) (2006), p. 1-62: Detailed historical commentary on the historical context of two dedications made during the reign of Leukon I (c. 389-349): a dedication to 
Phoibos Apollon by Leukon I in commemoration of a military victory (Semibratnee near Gorgippia; SEG XLVIII 1027) and the dedication of a propylon to Dionysos in Nymphaion (SEG LII 741).

113) A. Tziafalias - J.L. García Ramón - B. Helly, "Décrets inédits de Larissa", BCH 130 (2006), p. 435-483: Ed. pr. of an inscription of Larisa containing three honorary decrees; the inscription was to be set up in the sanctuary of Apollon Kerdoos (Larisa, c. 169 BCE).

114) E. VARINLIOĞLU, "East of Halicarnassus", in The Salmakis Inscription, p. 125-131: Ed. pr. of a fragmentary decree from Ouranion (1, Hellenistic period), with no comments. [The decree concerns major building activities in a sanctuary, probably of a goddess; it gives a board of functionaries the authorisation to move a statue (of the goddess?) and to tear down buildings, in order to improve the architectural setting), provides for funds, and allows these functionaries to sell building material from the sanctuary, which is no longer needed. I give

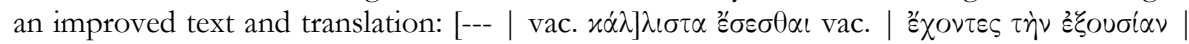

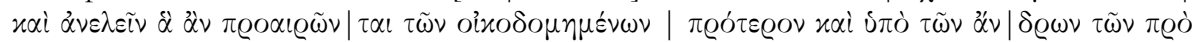

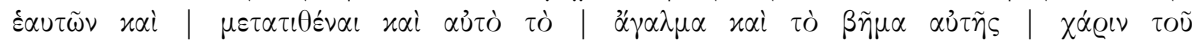

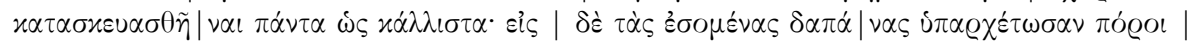

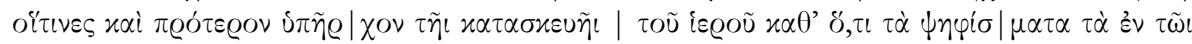

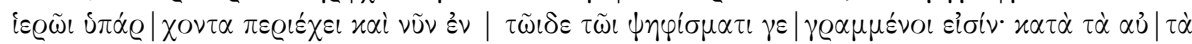

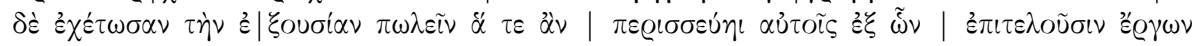

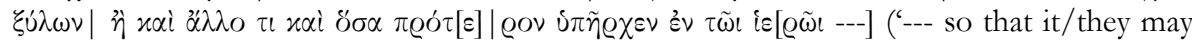
be as beautiful as possible, having the authorisation to tear down whichever construction they wish, of the buildings that had been constructed earlier by the men who were (responsible for the sanctuary?) before them, and also having the authorisation even to move the (cult) statue itself and her platform (i.e. the platform of the godess' cult statue), so that everything may be constructed in the most beautiful manner. For the expenses, there shall be the same funds as the ones that existed before for the construction of the sanctuary, as it is stated in the decrees that are in the sanctuary, as well as those (funds) that are mentioned in this decree. In the same way, let them have the authorisation to shell the surplus of timber, from the constructions which they make, and anything else, which was in the sanctuary before ---'). Ed. pr. of an altar (?) for a Roman emperor (3).

115) E. VARINLIOĞLU, "Five inscriptions from Acmonia", REA 108 (2006), p. 355-373 [BE 2007, 41]: Ed. pr. of an honorary decree for a priest of Athena Sebaste for life, who is

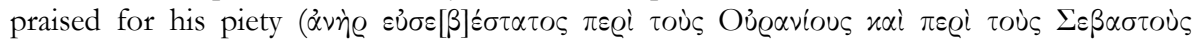

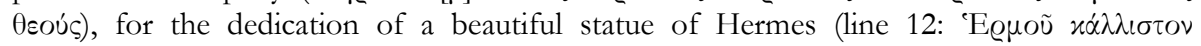
$\left.\alpha^{2} \nu \delta \varrho \varepsilon i \alpha \nu \tau \alpha\right)$, three other statues representing the people, the polis, and the gerousia, and a statue of Zeus Keraunios (Akmonia, $68 \mathrm{CE}$ ). [We note the distinction between the

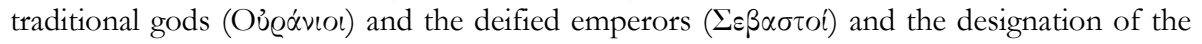
statue of Hermes as an $\left.\alpha \nu \delta \varrho \alpha^{\alpha} s.\right]$ The magistrates in the postscript include a priest of Aklepios Sebastos.

116) E. VARINlioĞLU - P. Debord, “Hyllarima 2004”, AST 23.1 (2005) [2006], p. 117-122: The authors report the discovery of the right part of a stele edited by A. LAUMONIER $(B C H$ 58 [1934], p. 345 no. 39). There is a Karian inscription on the top, followed by a Greek inscription that lists priests of Apollon (Hyllarima, 263/2 BCE).

117) C. VIAL, “À propos des concours de l'Orient méditerranéen à l'époque hellénistique”, Pallas 62 (2003), p. 311-328: V. presents an overview of the diffusion of agonistic festivals in Asia Minor and the East in the Hellenistic period. 
118) M. VondersteIn, Der Zeuskult bei den Westgriechen, Wiesbaden, 2006: Based on the literary, archaeological, and epigraphic evidence, V. discusses the cult of Zeus in the Greek colonies of Italy and Sicily. The largest part of the book is a description and analysis of the evidence for the cult of Zeus in the Greek cities. A short section (p. 217-228) is dedicated to a systematic discussion of general features of Zeus' cult: epithets, location of the cult places, rituals, association and assimilation of Zeus with other gods, and the development of the cult. Among the inscriptions which are discussed in some detail we single out a dedication to Zeus Meilichios in Kroton (Arena IV 41; p. 29-32); the boundary stones of Zeus' Agora and Zeus Aglaos (IGDGG II 42-44; p. 43-45) in Metapontion [on the problematic restoration $\Delta$ ıò $\dot{\alpha} \gamma \circ \varrho \alpha($ iov $)$ of. EBGR 2005, 51]; a dedication to Zeus Hikesios in Metapontion (IGDGG II 49; p. 53f.); a dedication to Zeus Xenios in Poseidonia (p. 66) [L. Dubois in IGDGG II 22 prefers not to amend the form Xeinos to Xenios]; a dedication to Zeus Soter in Lokroi Epizephyrioi (SEG XXIX 953; p. 104); a cippus of Zeus Orios in Elea (IGDS 51b; Arena V 36; p. 108-111); the Meilichios-stelae and the lex sacra of Selinous (SEG XLIII $630=$ NGSL 27; p. 199-213); and an inscribed kerykeion dedicated to Zeus Hikesios and found somewhere in East Sicily (SEG XLVI 1297; EBGR 1997, 247). As regards the lex sacra of Selinous concerning purifications, V. argues that Zeus Meilichios enjoyed a public cult, in addition to the private worship (p. 213). He interprets the kerykeion of Zeus Hikesios as a dedication by a herald after the fulfilment of a difficult task to a patron god.

119) R. WACHTER, “Die griechischen Inschriften”, in R.A. STUCKY, Das Eschmun-Heiligtum von Sidon. Architektur und Inschriften, Basel, 2005, p. 319-331 [BE 2006, 461; SEG LV 16511654, 1658, 1660-1666, 1679]: W. publishes the inscriptions from the sanctuary of Asklepios / Eshmoun in Bostan esh-Sheikh (near Sidon); only one of these texts was previously known. The texts include an honorary inscription for an agonothetes and priest (?) of Thea

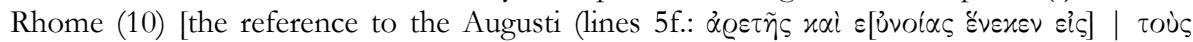
$\sum \varepsilon \beta\left[\alpha \sigma \tau \circ{ }^{\prime} \varsigma\right)$, suggests that this man had also served as a high priest of the Imperial cult]. Two texts record building activities of individuals and professional associations $(3,11)$. One of them commemorates the construction of an $\alpha x \tau \dot{\eta}$ (meeting and cult room?) by the guild

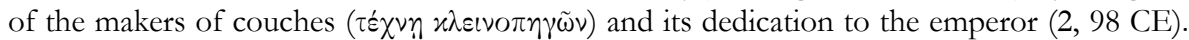
A priest and high-priest [according to P.-L. GATIER, BE 2006, 461, priest of Asklepios and high priest of the ruler cult made a dedication to Antiochos III, Laodike and their son

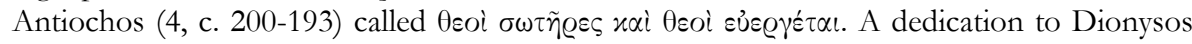
Kadmeios, i.e. the grandson of Kadmos of Sidon (5, 59 BCE), was made by Demokles, who

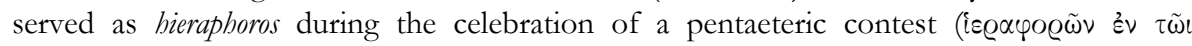

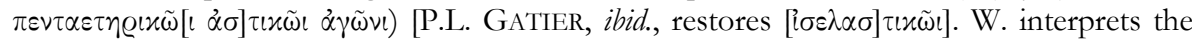

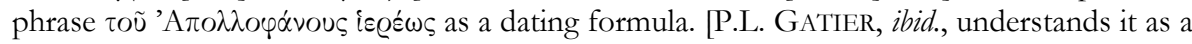

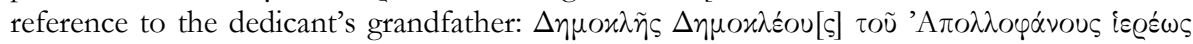
('Demokles, son of Demokles, grandson of Artemidoros, the priest')]. There are also six dedications to Asklepios (1-2, 6-9, 1st BCE-2nd cent. CE), made by associations of cutlery-

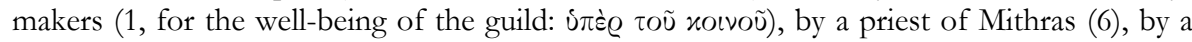

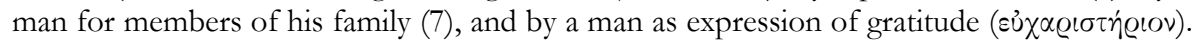

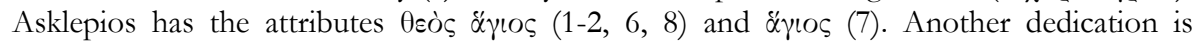
addressed to Aphrodite (7, undated). A small fragment mentions a high-priest (2).

120) C. WIKANDER, “The Practicalities of Ruler Cult”, in Greek Sacrificial Ritual, p. 113-120 [SEG LV 2095]: W. collects the epigraphic evidence for the cult of early Hellenistic kings (Lysimachos, Antigonos Monophthalmos, Demetrios Poliorketes, and Stratonike, Seleukos I, and Ptolemy I) established by cities and the Nesiotic League. The relevant evidence is limited to Athens and the Aegean basin (Euboia, Delos, Samothrace, Lemnos, Samos, coast of Asia Minor) [one may now add the cult of Philetairos in Kyme: SEG L 1195; EBGR 
2000, 126]. The rituals (processions, sacrifices, contests, erection of cult statues) did not differ from those of pre-existing cults of gods, on which the ruler cult was modelled. W. concludes that the ruler cult was modelled on already existing patterns of worship [cf. A. Chaniotis, "Isotheoi timai : la divinité mortelle d'Antiochos III à Téos", Kernos 20 (2007), p. 153-171].

121) M. Youni, "Maîtres et esclaves en Macédoine hellénistique et romaine", in V.I. ANASTASIADIS - P. DOUKELlis (eds.), Esclavage antique et discriminations socio-culturelles. Actes $d u$ XXVIIIe colloque international du Groupement International de Recherche sur l'Esclavage antique (Mytilène, 5-7 decembre 2003), Frankfurt, 2005, p. 183-196: Y. gives a very good overview of the information provided by the inscriptions of Macedonia concerning the manumission of slaves, often in the form of a dedication to a goddess (e.g., IG X 2.2, 18 and 233; SEG XXXVI 617; XXXVIII 632, XXXV 750). The most substantial part of this article treats the dedications of slaves to Meter Theon Autochthon in Leukopetra. Y. regards these dedications as 'de véritables actes d'affranchissement, qui produisent tous les résultats juridiques' and argues that they resulted in the liberation of the slaves, who were only obliged to serve

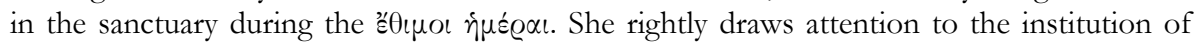
$\pi \alpha \varrho \alpha \mu o v \eta \dot{~(c f . ~} \pi \varrho \circ \sigma \mu \varepsilon \dot{v} \omega$ in I.Lenkopetra 25 and 37) and the use of a vocabulary similar to that

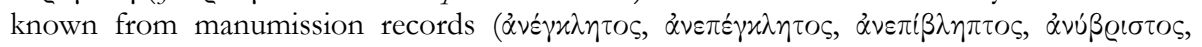

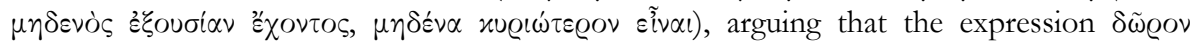
$\delta i \delta \omega \mu$ corresponds to é $\lambda \varepsilon \cup \theta \varepsilon \varrho o ́ \omega(c f$. the use of both expressions in I.Beroia 49). She interprets the term $\dot{\omega} \nu \dot{\prime}$ as an indication that the manumitted slaves had paid a price for their manumission (192: 'c'est l'emploi de ce terme qui indique que l'esclave, en fait, se rachetait. Le fait que le prix du rachat ne soit pas mentionné dans les sources épigraphiques n'est pas décisif'). She also comments on the registration of the donation ( $\left.\alpha \alpha \alpha \gamma \varrho \alpha \varphi \eta^{\prime}\right)$ and the decree of the governor of Tertullianus Acquila regulating manumissions in sanctuaries (212 CE). [Although the donations of slaves to the Mother of the Gods at Leukopetra certainly had legal implications that did not differ substantially from a manumission, the texts make clear that the dedicants regarded these acts as donations, not as manumissions; in many cases the donated slaves were children, in other cases the donation was explicitly in fulfilment of a vow, and there are also cases in which slaves were bought only in order to be dedicated (I.Lenkopetra 57 and 78); in one case a lost slave was dedicated to the goddess in the hope that she would find him (I.Leukopetra 53); this clearly is not a manumission; for all these reasons one should make a distinction between manumissions and these donations of slaves (cf. EBGR 2000, 155). I should also add that $\dot{\omega} v \eta \dot{~ i n ~ t h e s e ~ t e x t s ~ d o e s ~ n o t ~ m e a n ~ p u r c h a s e ~ b u t, ~}$ generally, 'title of ownership'.]

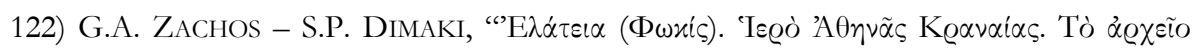

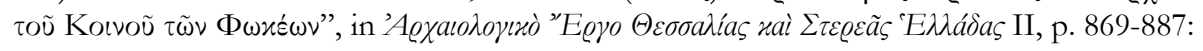
Overview of archaeological research in the sanctuary of Athena Kranaia (Elateia in Phokis). The epigraphic finds (IG IX 1, 97/98, 101, 110-115; cf. I.Magnesia 34) show that this sanctuary was the place where the assembly of the Koinon of the Phokeis was summoned.

All Souls College

Angelos CHANIOTIS OXFORD OX1 4AL

E-mail: angelos.chaniotis@classics.ox.ac.uk 